\title{
Bland turister och araber. Juho Rissanen på hälsoresa i Biskra 1931
}

Marie-Sofie Lundström

Den Kuopiofödde Juho Rissanen (18731950) är främst känd som skildrare av det finska folket. Den del av hans produktion som känns till av den stora allmänheten och som gått vidare i konsthistorien är koncentrerad till tiden kring sekelskiftet 1900, då hans skildringar av det finska folket fick stort erkännande. ${ }^{1}$ Till hans produktion hör även monumentalmåleri (fresker) och glasmålningar, samtliga med finska motiv. I Svenska Pressen stod det att läsa 1931 att "Rissanen [...] är det finska folkkynnets målare, kolbrännarnas och skeppsbyggarnas", ${ }^{2}$ vilket bra sammanfattar den bild man får i konsthistorisk litteratur, ${ }^{3}$ även om hans konst på senare tid har omvärderats. ${ }^{4}$ I den här arti- keln detaljgranskas emellertid Rissanens fyra månader långa vistelse $1931 \mathrm{i}$ den omtyckta kurorten Biskra vid den algeriska öknen, vilket kan anses vara ett uttryck för fransk kolonialmaktsturism. Många européer, främst fransmän men även turister och andra slags resenärer från flera andra europeiska länder och USA, lockades av staden vid Saharaöknens rand, främst med avsik-

Bild 1. Env. De Biskra. Un Chamelier. Edition Marius Maure, Biskra. Postkort skickat av Rissanen till Eemil Suihko. Biskra 29.12.1930. Kuopion taidemuseo/Kuopion isänmaallinen arkisto.

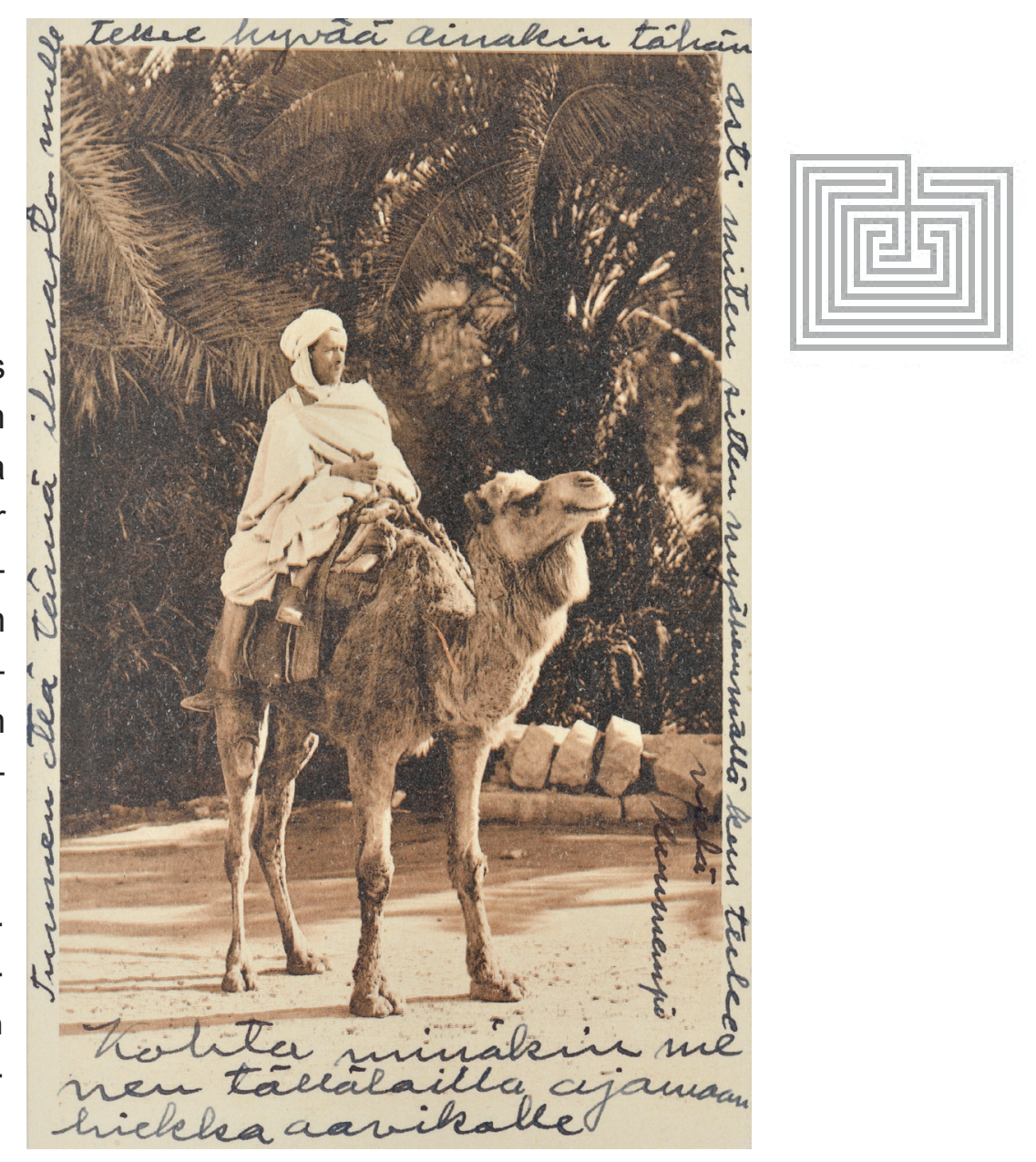


ten att sköta sin hälsa i ett tjänligt klimat. Det var medan Rissanen bodde i Paris som han beslöt sig för att åka till Algeriet, som då var en fransk koloni, vilket gör att resan kan inplaceras i ett större, franskt fenomen.

\section{Problemställning: korrespondens, tex- ter och bildmaterial}

Greppet är historiskt-deskriptivt, syftet är att inplacera Rissanens Biskraresa i ett större sammanhang bestående av fransk kolonialmaktsturism; hans resa ingår i ett relativt utbrett fenomen. Det empiriska materialet öppnar sig för en närmare granskning av hans upplevelser och iakttagelser, och orsakerna till varför han överhuvudtaget begav sig dit. I det följande granskas hans resa i tre olika kontexter: Biskra som turistmål (hälsoresenärens Biskra), den orientalistiska genren inom måleriet och Rissanens sena produktion. Kontexten är främst kulturhistorisk, varför hans teckningar och akvareller och eventuella konstnärliga influenser inte analyseras i detalj.

Rissanens akvareller och teckningar från Biskra finns bevarade i Kuopion Kulttuurihistoriallinen Museo/Kuopion taidemuseo (dep.), och på Åbo konstmuseum. ${ }^{5}$ Förutom själva bilderna ligger som grund för rekonstruktionen av resan hans korrespondens, som består av de några postkortsbrev som han skickade till Eemil Suihko, journalisten Irja Spira, bosatt i Paris, vännen och finskhetsivraren Ellinor Ivalo, Rissanens finländska livmedikus Kaarlo Taskinen och konsthistorikern Onni Okkonen, som hade skrivit en monografi om Rissanen (publ. 1927). ${ }^{6} \mathrm{En}$ annan viktig primärkälla är en intervju med Rissanen, publicerad i Konstrevyn i oktober 1931, i vilken konstnären berättar om sin tid i Biskra. ${ }^{7}$

Vidare utnyttjas reseskildringar för att skapa en bild av hur Rissanens samtid och utlänningar såg på staden, framför allt Nils Wilhelm Lundhs En författares resa Nord-Afrika från 1924, i den ingår många illustrationer i form av fotografier tagna av författaren. ${ }^{8}$ Reseskildringen är utgiven endast några år före Rissanens resa, och fungerar därför som en bra referens till vad han kunde se på ort och ställe; i boken ingår kapitlet "Biskra på gott och ont". Vidare utnyttjas en betydligt tidigare fransk guidebok, den högt skattade Hachettes Guides-Joanne. Algérie et Tunisie (1905), som beskriver stadens sevärdheter på många sidor, vilket betyder att
Biskra redan tidigt var en turistattraktion. En annan publikation som bidragit med värdefull information, och som innehåller många citat främst från tidiga betraktelser från Biskra, är Gareth Stantons artikel "The Oriental City: A North African itinerary" (2008). Guideböckerna och reseskildringarna riktar sig till den stora allmänheten (det förmögnare borgerskapet), och ger ovärderlig information, eftersom det Biskra som skildras i dem inte längre existerar.

Därtill är bilderna på de postkort som Rissanen använde som brevpapper intressanta eftersom de illustrerar vad man som utlänning i Algeriet väntade sig att se och uppleva under sin vistelse. Rissanen skrev på baksidan av postkort och förseglade dem i ett kuvert och skickade dem som vanlig brevpost, varför de postkortsmotiv han valde är värda att diskutera närmare; postkortens motiv utgör ett representativt genomsnitt av dylika vykort från den tiden. ${ }^{9}$

Ytterligare en publikation som med viss reservation kan användas som källa är amerikanskan Clara Stockers levnadsskildring Paitasetä. Juho Rissasen elämä (utg. 1993): den bygger på författarens personliga minnen av konstnären, som hon träffade 1930 
och 1933, men är besvärlig att använda då den inte har hänvisningar. Det tog åtskilliga år efter deras möten tills det engelska manuskriptet översattes till finska och publicerades. ${ }^{10} \mathrm{I}$ den ingår knappa två sidor där Biskra diskuteras, men greppet är skönlitterärt och texten kan inte utnyttjas som pålitlig källa. Publikationen utnyttjas dock ställvis för att komplettera några uppgifter som inte hittas i primärmaterialet, i och med att deras möte 1933 skett relativt nära Rissanens vistelse i Biskra. Men texten är tendentiös och uppfyller inte samtidskriteriet. Man bör således iaktta försiktighet då man använder uppgifterna.

\section{En konstnär på resande fot}

Enligt Irene Moilanen präglades den senare delen av Rissanens liv av rastlöshet: han var neurotiskt rädd för sjukdomar och krig och valde sin boplats enligt det. Från och med 1918 vistades han för det mesta utomlands, först i Danmark och därefter i Frankrike. ${ }^{11}$ Efter den årslånga vistelsen i Danmark reste han till London, Florens och Rom, men efter det befann han sig här och där i Frankrike: Pyreneerna, Nizza, Menton, Cannes, Saint-Paul-de-Vence, Saint-Germain-en-Laye och så vidare. Under 1920-talet reste han ånyo till Florens och Rom, samt återvände till Danmark för en kortare period. ${ }^{12}$ Han var således relativt rörlig under största delen av 1920-talet, men senare var han för det mesta stationerad i Paris (1926-1935). Därefter tillbringade han åren 1936-1939 i Nizza. Han besökte Finland endast under somrarna. ${ }^{13}$ Sista delen av sitt liv var han bosatt i Miami, var han dog 1950, 77 år gammal. ${ }^{14}$

Men Rissanen hade redan under sin vad man kan kalla glansperiod kring sekelskiftet 1900 idkat studier utomlands i flera repriser. I Onni Okkonens levnadsskildring från 1927 gör Okkonen sitt bästa för att peka ut hur Rissanens studier bidragit till hans patriotiska uppgift som skildrare av det finska folket. Men speciellt då han beskriver Rissanens experiment och kontakt med de nyare konstströmningarna kan man mellan raderna läsa att inflytandet från den moderna samtidskonsten inte alltid var så önskvärt. Efter studier i bland annat S:t Peterburg och i Italien började Rissanen vistas allt mer i Frankrike, och Okkonen konstaterar att Rissanens konstnärliga mål nu förändrades, både i stil och i innehåll. Men hans utländska, "parisiska" konst förtjänar inte samma erkänsla som de tidigare verken, konstaterar Okkonen. ${ }^{15}$ Så småningom, efter vistelser i Köpenhamn och den franska landsbygden, glider Rissanen allt mer in i den internationella, från Paris styrda konsten. Hans stil började lösa upp sig, och hans verk innehöll inte längre samma vitalitet som tidigare, anser Okkonen. ${ }^{16}$ Detta påverkade givetvis hur man snare, hemma i Finland, uppfattade den medelålders Rissanen, vilket jag återkommer till i slutet av artikeln.

En intressant aspekt förknippad med Rissanens Afrikaresa, om ej direkt, är hans intresse för afrikansk folkkultur. I Kuopio kulturhistoriska museums samlingar finns en ansenlig mängd föremål (82 stycken) som han donerade under loppet av 1930-talet och som kan karakteriseras som afrikansk folkkonst: masker, statyetter, bruksföremål, smycken och instrument från Elfenbenskusten. Föremålen skaffade han medelst en bekant som var bosatt där - Rissanen har inte själv rest i de områden varifrån föremålen härstammar, utan Biskra förblir det mest exotiska resmålet. Av de donerade föremålen är dock endast enstaka från Algeriet. Utöver de afrikanska föremålen donerade han också ett större antal asiatiska föremål 
och målningar från bland annat Kina, Indien och Japan, föremål som han sannolikt skaffade i Paris med den uttryckliga intentionen att donera dem till museet i Kuopio.17 Hans samlande indikerar att främmande kulturer intresserade honom, även om han inte vistades utanför Europa annat än under sin resa till Algeriet 1931, vilket här kommer att diskuteras i detalj.

\section{Biskra och kolonialmaktsturism}

"Den turist, som avskyr turister och som helst vill stå ensam i sitt slag i solen med sin nyfikenhet eller med sina snåla drömmar i månskenet, bör helst undvika Biskra, där det är gott om främlingar." 18

- Nils Wilhelm Lundh, En författares resaNord-Afrika, 1924

Vistelsen i Biskra innebar en snabb och komfortabel introduktion till ökenlivet. Det som fascinerade resenärerna i Biskra var det som man upplevde som annorlunda jämfört med Europa: det var främst öknen som lockade resenärerna dit, med allt vad det innebar. Det som jag vill kalla för "ökenturism" lockade, förutom det milda vinterklimatet, med sin närhet till viktiga oaser, och öknen, och stadens pittoreska gamla kvarter. Resenärerna kom till Biskra för att så att säga smaka på öknen, dess lukter, ljuset och storskaligheten. ${ }^{19}$

Frankrike erövrade Algeriet av ottomanerna 1830, och genast efter de inledande oroliga decennierna som resulterade $\mathrm{i}$ att Algeriet blev fransk koloni 1844, inleddes kolonisationsprocessen. Alt fler européer bosatte sig i landet, förutom militärer även konstnärer och författare, samt fotografer, som spred sin bild av Algeriet till europén: förutom reseskildringar cirkulerade hundratals målningar, gravyrer och fotografier av algeriska scener på marknaden. Fotografiet var ett relativt nytt medium, och från och med mitten av 1800-talet började illustrerade häften cirkulera på den europeiska marknaden, ofta med understöd av det franska Ministre de la Guerre, liksom brittiska motsvarigheter. De illustrerade häftena gick för det mesta under namn som Souvenirs de l'Algerie eller L'Algerie photographiée, och innehöll texter om Algeriets historia och geografi, tips för turister och anmärkningar om klimat. Den algeriska bildrepertoaren etablerades snabbt bland utlänningarna, även utanför Frankrike: stadscentra (inledningsvis i första hand från Alger), romantiska ruiner, pittoreska vyer, oaser, arabiska byar, franska kolonier, och porträtt av civila och militärer. Till motiven hörde även fotografier på ursprungsbefolkningen, dansande kvinnor och fotografier som kan klassificeras under rubriken "seder och bruk". Vidare förekommer en och annan nakenbild, odalisker och slavar. ${ }^{20}$

Algeriet visualiserades således tidigt, så småningom även Biskra. Staden blev allt mer sägenomspunnen, dess rykte spreds från mun till mun både bland det penningstinna borgerskapet och i bohemiska kretsar, i första hand i Frankrike men även i det övriga Europa. De allt livligare strömmarna av utlänningar i Biskra från och med slutet av 1800-talet ledde snabbt till att guideböcker och reselitteratur som behandlar Algeriet, kom att inkludera skildringar även därifrån. På det viset fick Biskra så småningom status som turiststad och omtyckt resmål, även bland bohemiska konstnärer; den mentala bilden av staden skapades genom allt från illustrerade reseskildringar, dokumentärfotografier, iscensatta bilder som postkorten och de i fotoalbumen, till konstnärernas syn på det exotiska och deras målningar med orientalistiska motiv. ${ }^{21}$

Men innan detta kunde ske måste drömmen om Biskra skapas. I Paul Bourdes re- 
seskildring från 1880 utbrister han: "Åh Biskra! Den som har sett dig, kan aldrig glömma!" Men inledningsvis var det inte så. Det tog många decennier efter annekteringen med Frankrike innan man kunde skapa dammar kring staden för att t.ex. tillgodose vattentillförseln i området. Ännu på 1850-talet hade resenärer i Algeriet lite att säga om Biskra, men 1875 var situationen en annan. $\mathrm{Nu}$ handlar det i reselitteraturen inte enbart om militära bedrifter eller geografiska omständigheter som dittills. Förutom fransmän reste nu också engelsmän dit, vilket framgår av de publicerade reseskildringar i vilka Biskra började diskuteras mer ingående. ${ }^{22}$ Förutom Lundhs reseskildring från 1924, som här får exemplifiera en skandinavisk skildring, var antalet europeiska reseskildringar, ofta med illustrationer, överväldigande: förutom på franska, utgavs de på många andra europeiska språk, bland annat engelska och tyska.

Även om många reste till eller bosatte sig i Biskra snart efter annekteringen, började den egentliga turismen i Biskra således på allvar först från och med 1870-talet, stegrades kring sekelskiftet 1900 och fortsatte långt in på 1900-talet fram till andra världs- kriget, varefter det blev allt svårare att resa i det politiskt oroliga landet. Efter att Algeriet blivit självständigt 1962 har landet inte utvecklats i samma riktning som t.ex. Tunisien och Marocko, som båda har internationell turism idag.

Numera är det främst den nationella turismen som är viktig för Biskra, som är huvudstad i en större provins. Under 1900-talet har Biskras invånarantal stigit stadigt: 1907 bodde 7.500 personer i staden, men redan 1911 var invånarantalet strax över 10.000. Denna snabba tillväxt i befolkningsmängden bottnar i att det ekonomiska läget i staden förbättrades tack vare ökad turism. År 1931, då Rissanen besökte staden, var invånarantalet 18.900, medan provinsen Biskra idag omfattar en stor areal med över 300.000 invånare. ${ }^{23}$ Biskra är således en modern stad som inte på något vis erinrar om svunna tider, eller tiden för Rissanens besök. Bland annat förstördes den gamla stadsdelen, inklusive kasbah, i en flodvåg 2005. Området har nu fyllts upp av moderna byggnader för dem som förlorade sina hem i översvämningen och få pittoreska byggnader finns kvar. ${ }^{24}$

I Guides-Joanne beskrivs däremot många sevärdheter. Efter en allmän notering om ho- tellen följer en många sidor lång utredning över vad man som europeisk turist kunde se i staden, men också utfärder utanför Biskra. Guideboken rekommenderade bland annat en "village nègre", nog tillräckligt intressant för att vara värd ett besök ("assez peu intéressant"). Därtill berättar guideboken att man kunde resa till Touggourt, en ökenstad en bit söder om Biskra i Saharaöknen, eller till Bou Saâda som ligger till väst på samma höjd som Biskra. Enligt Guides-Joanne kunde man nå dessa städer relativt lätt. ${ }^{25} \mathrm{På}$ Rissanens tid gällde även biltransport; bilen ersatte så småningom andra fortskaffningsmedel. I en intervju från 1933 med Oscar Parviainen som besökte Biskra vintern 192627, får vi läsa att "Ford har betydligt fördärvat det gamla Afrika", han drömde sig tillbaka till en tid då Algeriet inte ännu var det turistland det kom att bli. ${ }^{26}$

Vidare gjorde Algeriets ställning som fransk koloni att man kunde resa till det exotiska landet utan allt krångel som hör samman med utlandsresor. De första resenärerna var naturligt nog fransmän, även om engelsmännen och turister från andra europeiska länder följde tätt efter. Turistskarorna i Biskra, som ofta var den ort som lockade 
dem till Algeriet, gjorde att infrastrukturen utvecklades i en "västerländsk" riktning. Det behövdes hotell och andra tjänster för turisterna; redan i Guides-Joanne får vi läsa att där fanns många och bekväma hotell, några av dem rentav pampiga och stora. ${ }^{27}$ Turisterna behövde ett visst mått av service och bekvämligheter. Den allt livligare turismen gav upphov till en västerländsk infrastruktur, vilket gynnade turismnäringen, som i sin tur påverkade behovet av ytterligare byggnationer. Turismen hade en direkt inverkan på stadsutvecklingen och ekonomin, och vice versa.

Det var även förhållandevis lätt att resa till Biskra, trots det avlägsna läget. Järnvägsnätet i norra Algeriet var relativt väl utbyggt, liksom mer söderut, ända till Biskra som var slutstation där öknen tar vid; järnvägen från Constantine i norr sträckte sig ända ner till Biskra 1888. ${ }^{28}$ Enligt den utförliga Bradshaw's Continental Railway Guide från 1913 räckte tågresan från Constantine dryga 81/2 timmar, åtminstone i teorin - på Rissanens tid gick resan troligtvis snabbare. På kartan som är bifogad ser man tydligt att järnvägsnätet i Algeriet, och det i Tunisien, var väl utbyggt; Biskra är den mest sydliga algeris-

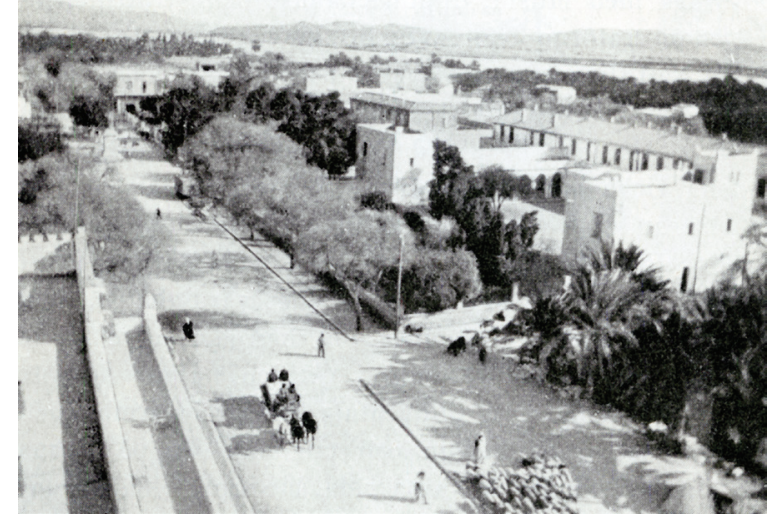

Bild 2. Biskra: från Royals minaret, Lundh, 29.

ka orten som man kunde nå medelst tåg. ${ }^{29}$ Tågförbindelsen gjorde det enkelt att ta sig dit, resan var relativt riskfri för den vanliga resenären. Biskra med omgivningar ingick även i Thomas Cooks ökenexkursioner, som ordnades från och med 1880-talet. ${ }^{30}$

Den koloniala aspekten yttrar sig speciellt tydligt $\mathrm{i}$ att fransmännen från och med 1840-talet påverkade stadsbilden och -kulturen, liksom förvaltningen. Fransmännen odlade en egen Medelhavskultur i Algeriet, och stadsbilden påverkades av fransmännens nybyggnader och förändringar i gatunätet, främst i huvudstaden Alger men också i Biskra som hade en nybyggd stadsdel, nära det gamla Biskra. Den nya, västerländska stadsdelen låg strax intill järnvägsstationen. Staden var tydligt tudelad i en gammal och en ny stadsdel, Guides-Joanne talar om "La ville française", som ligger uppströms om oasen. ${ }^{31}$ Det var i den franska stadsdelen som Rissanen bodde på det anrika Hôtel du Sahara, de flesta av hans brev är daterade där. Hotellet är byggt i kolonial stil, och är beläget alldeles mitt i stadskärnan. ${ }^{32}$

Den gamla staden var dock mer pittoresk, byggd på ruinerna av en romersk fästning. Från den nya stadsdelen kunde man åka på exkursioner till det gamla Biskra med

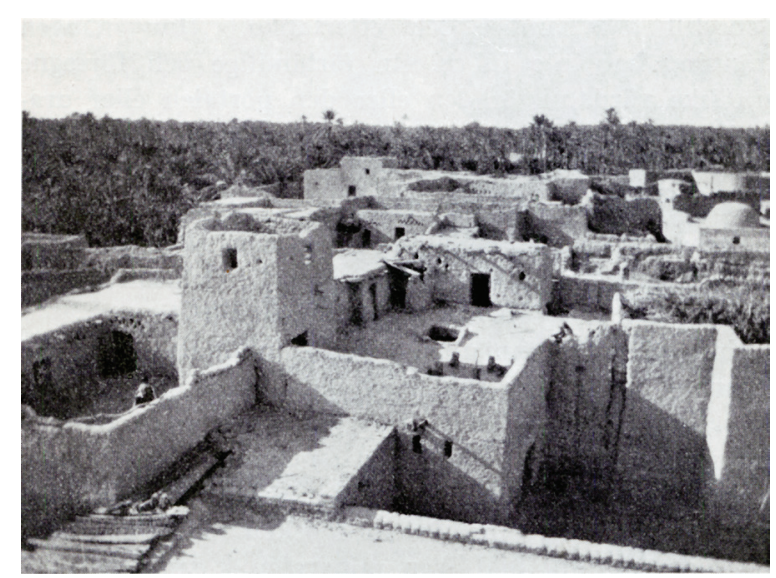

Bild 3. Gamla Biskra, från minareten, Lundh, 51. 
spårvagn. ${ }^{33}$ Där kunde man stifta närmare bekantskap med ursprungsbefolkningen medelst ett slags "etnoturism", och besöka "riktiga" moriska bad och byar, kvarter med magdansöser, och naturligtvis kamelutfärder i öknen. ${ }^{34}$ Enligt Lundh tog det inte ens länge: "Vill man se en helt arabisk stad, och vem vill inte det, är Biskra den bästa utgångspunkten - man har då gamla Biskra en halv timmes väg borta. ${ }^{35}$

Samtidigt var det billigt att leva i Biskra. Lundh observerar att också skandinaverna började bli rätt välkända där i och med att turistströmmen söderut allt mer sökte sig mot Nordafrika, främst beroende på de oerhört stegrade priserna i de mer kända resmålen $\mathrm{i}$ Europa, t.ex. Italien där man fick betala främlingsskatt. Algeriet och Tunisien var guldlandet, levnadsomkostnaderna var i genomsnitt enbart femtio procent av hemlandets. ${ }^{36}$ Också detta torde ha gjort Biskra attraktivt för Rissanen, som var i behov av pengar under sin vistelse där, även om turismen trissade upp priserna. ${ }^{37}$ Rissanen reflekterar:

"Annars är araberna i grund och botten goda människor, fastän turismen nog har skadat dem mycket. De ha lärt sig att alltid begära det högsta möjliga pris för vad det än gäller. Jag minns när jag skulle ha en modell. En hel flock unga flickor hade anmält sig och när vi kom till prisfrågan begärde den först $300 \mathrm{fr}$. i timmen. Strax började de andra bjuda under och när vi hållit på en stund fick jag en för $2 \mathrm{I} / 2$ franc $\mathrm{i}$ timmen. På samma sätt var det när jag skulle köpa en ring. - Fyrtio franc, sade araben. Tjugo får ni, sade jag. Då såg han långt på mig och sade: Du kan simma, vilket på svenska betyder "du kan pruta"..$^{8}$

Också enligt Clara Stocker var Rissanen skicklig på att pruta, speciellt då han skulle ha modell; i hennes berättelse anges samma summor som i citatet ovan. ${ }^{39}$ Men det kostade att leva i Biskra även om det var billigare än annorstädes. Till en del finansierade Eemil Suihko Rissanens vistelse där. ${ }^{40}$ Suihko hade beställt en målning, Lingonrensarna (Puolukan puhdistajat), som vid tiden för vistelsen i Biskra var kvar i Paris; han lovar skicka målningen så fort han återvänt $i$ april. Men Rissanens resebudget var ansträngd, varför han ber Suihko om att få betalt för sitt arbete redan nu, medan han ännu befinner sig i Biskra; brevet är daterat i Biskra den 29 december $1930 .{ }^{41}$ Rissanen fick sina pengar, han fick ordning på sin budget och kunde stanna i Nordafrika som planerat.

Eftersom den franska närvaron i Biskra var påtaglig är det ingen överraskning att Rissanen som halv fransman beslöt sig för att åka just dit. Men i intervjun i Konstrevyn talar han om den vilseledande "Biskrareklamen":

"Men det allra första man erfar när man kommer till Biskra, den stad där jag bodde längst, är en djup och grundlig besvikelse. Man hade väntat sig ett paradis - enligt reklamen - och finner en håla mitt i den ändlösa öknen, som förresten ser förfärligt trist ut när det regnar; och det gjorde det när jag kom dit. Se, det är det med Biskra och öknen att det skall vara sol - annars är där hemskt. Men skiner solen är där mycket ljuvligt med lätt och klar luft och över dådigt praktfulla solnedgångar. Livet $i$ staden är också mycket pittoreskt och säreget, helt annorlunda än i Europa och de ständiga kamelkaravanerna se så egendomliga och frămmande ut. ${ }^{42}$

\section{Biskra - en plats för hälsoresenären}

Tillströmningen av turister i Biskra grundar sig framför allt på att staden tidigt blev berömd för sitt milda klimat och sina källor, vilket ledde till en allt livligare turism. På grund av det behagliga klimatet stannade många turister över vintern, så också Rissanen. Han skriver till Eemil Suihko: "Kuten näet olen minä vetäytynyt tänne saamaan keuhkojen täydeltä ilmaa, ja aurinkoa". (Som du ser har jag dragit mig tillbaka hit för att få lungorna fulla med luft, och sol.) Suihko var läkare vid Länssjukhuset i Åbo. ${ }^{43}$ Under den tid Rissanen vistades i Biskra var han 58 år, och hade hunnit samla på sig en hel 
del krämpor och symptom, vilka han regelbundet återkommer till i sin korrespondens - redan under perioden i Danmark hade han vistats på sanatorium i Fredriksberg, och senare i Frankrike på sanatoriet i La Bourboule $1924 .{ }^{44}$

Men trots dess rykte som en hälsosam ort, förskräckte förhållandena i (det gamla) Biskra. Även Rissanen noterar i ett brev till Onni Okkonen:

Olen täällä nyt ollut melkein kolme viikkoa ja kyllähän täälläkin aika menee kun alkuun pääsee vaikka se tuntuu ensin oudolta ja yksitoikkoiselta, vaikkakin heti ensi silmäykseltä loistavaltakin ja maalaukselliselta ja sitähän tämä elämä on täällä kokonaan - mutta kauhea likapesä on tämä paikka, ihmettelen kuinka nämä ihmiset (arapialaiset) voivat elää että eivät kuole sukupuuttoon likansa vaikutuksesta, mutta eipäs, eläävät vaan niin kun muutkin, mutta tämä ilmasto on se joka ne pystyssä pitää ja niin elämä pyörii täällä eteenpäin päivästä toiseen ja arapialaiset ja me muut maatiais ihmiset elämän mukana siksi kun kukin kerrallaan tipahtaa jonnekkin. ${ }^{45}$

[Jag har nu varit här nästan i tre veckor och visst går tiden också här bara man kommer igång fast det först känns underligt och enformigt, även om det genast vid en första anblick även verkar till och med fantastiskt och måleriskt och det är ju det här livet helt [och hållet] - men ett hemskt smutshål är det här stället, undrar över hur dessa människor (araberna) kan leva så att de inte dör $i$ utrotning på grund av deras smuts, men si nej, de lever bara som andra, men det är detta klimat som håller dem uppstående och så rullar livet vidare från en dag till en annan och araberna och vi andra lantliga människor med livet tills en efter en tuppar av någonstans.]

Även Lundh har anmärkningar på invånarnas renlighet och förhållande till sjukdomar. Speciellt upprörande var arabernas vana att trampa i de varor (bl.a. dadlar) som såldes på marknaden, och koppningen. Han suckar uppgivet: "Att befolkningssiffran likväl kan hålla sig så högt uppe har man kanske ändå solen att tacka för!"46

Eftersom några brev från Biskra är riktade till en läkare (förutom Suihko hans finska livmedikus Kaarlo Taskinen) är det givetvis naturligt att han fäster uppmärksamhet vid sitt hälsotillstånd, men samtidigt är hans kommentarer uttryck för den tidens strävan efter att leva ett sunt liv, vilket blir tydligt i framför allt breven till Suihko. Han klagar bland annat på krångel med levern och hemorrojder, och funderar på att efter Afrikavistelsen åka till kurorter i Europa: han nämner Vichy, Karlsbad (Karlovy Vary) och Bulgarien, alla välkända kurorter. Bland annat Karlsbad blev populärt under 1800-talet på grund av platsens varma källor, men kanske främst för att många celebriteter besökte orten med avsikt att hälsobada (bland de mer kända hittar vi till exempel Goethe och Beethoven). Han noterar dessutom att det i Karlsbad ska finnas "ihmelähteitä" (ung. "underverkskällor") och att livet där är billigt. Vet Suihko något mer om förhållandena och behandlingssätten där? ${ }^{47}$ Hälsokurer och helande källor verkar ha legat Rissanen varmt om hjärtat.

Enligt Kirsi Moilanen var det milda vinterklimatet och de helande källorna vid oaserna nära staden som förde Rissanen till Biskra. ${ }^{48}$ Staden var känd uttryckligen för sina svavelkällor, Hammam Salahin, som fortfarande idag används för att lindra reumatiska besvär och för att sköta hudsjukdomar. Seden går tillbaka ända till den romerska tiden då området var en del av provinsen Numidien. I Bradshaw's Continental Railway Guide från 1913 ingår en sammanfattande text om det under vinterhalvåret så välbesökta Biskra, som beskrivs som en oas vid öknens rand, känd för sitt varma och torra klimat. Enligt beskrivningen kunde de varma svavelkällorna lindra reumatiska besvär. Vidare noteras att där fanns ett casino och en teater, vilket innebär att staden redan genomgått en betydande västernisering. ${ }^{49}$ Det var populärt att tillbringa tid vid källorna - man ansåg att vattnet hade hälsofrämjande egenskaper och skulle avnjutas både in- och utvändigt $\mathrm{i}$ 
ett behagligt klimat. Redan 1875 hade engelsmannen George Gaskell noterat att dåtidens läkare höll med om att staden förenade alla naturens "klimatiska fördelar" på ett och samma, behagliga ställe. ${ }^{50}$

I sin korrespondens nämner Rissanen inte källorna explicit, men återkommer istället ofta till det för hans hälsa så ypperliga klimatet. ${ }^{51}$ Han skriver till Eemil Suihko i mitten av februari: "...täällä nyt vasta rupee tulemaan ne oikeat lämpimät ja sitähän varten minä tänne tulin niin täydyn käyttää hyväkseni niin paljon kun vain." (...här börjar först nu det riktigt varma [vädret] och det är ju för det som

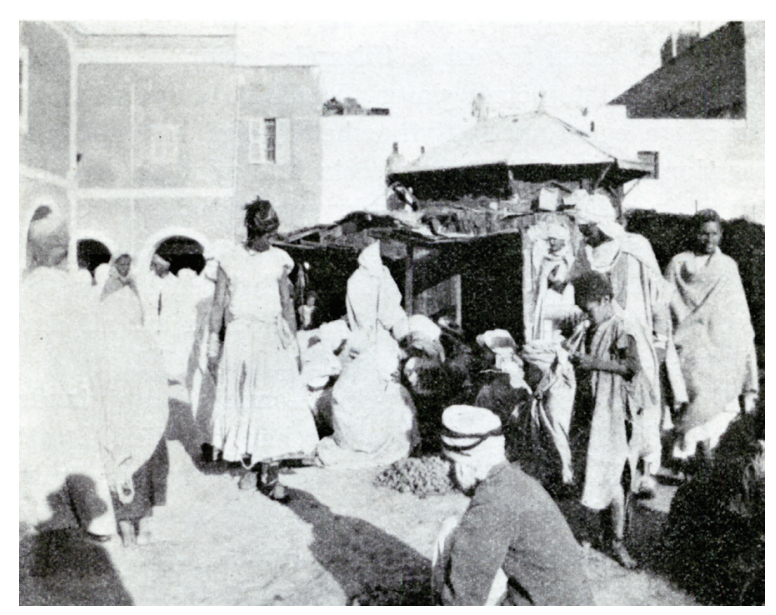

Bild 4. Torget i Biskra, Lundh, 41. jag kom hit, därför måste jag utnyttja det så mycket som [jag kan])." Rissanen stannade i Nordafrika ända fram till april, och kunde sålunda dra full nytta av det torra och varma klimatet i ökenstaden..$^{52}$ Han skriver också till Onni Okkonen om det behagliga vädret:

"Tulin tänne vähän saamaan aurinkoa ja lämmintä ilmaa korvilleni ja katarilleni, jotka rupesivat pariississa liikaa kiusaamaan kun ei muuta kun koko ajan satoi niin että koko pariissi oli hukkua ja ihmiset mukana." ${ }_{53}$

[Jag kom hit för att få lite sol och varm luft för mina öron och min katarr, som började besvära mig för mycket i Paris då det regnade hela tiden så att hela Paris höll på att drunkna och människorna därmed.]

Enligt Clara Stockers levnadsskildring hade Rissanen rest till Biskra för att sköta sin bihåleinflammation, som plågat honom i Köpenhamn och som påverkat hans hörsel. ${ }^{54}$

Rissanen nämner sina öron och katarren också i ett brev till Ellinor Ivalo, och skyller på det fuktiga vädret i Paris. ${ }^{55}$ Vidare rekommendrar Rissanen Biskra även för Eemil Suihko, "Luulen että lääkärinä olis sulle suuresta arvosta tulla tänne tutkimaan täkäläistä ilmastoa joka on inmeellinen kuiva kevyt ja lämmin." (Jag tror att du som läkare skulle uppskatta mycket att komma hit och under- söka detta klimat som är förunderligt torrt, lätt och varmt). ${ }^{56}$

I Biskra levde Rissanen ett hälsosamt liv, helt i enlighet med hans strävanden att sköta sin hälsa. I det ingår att följa en vegetarisk diet, vilket kan ses som uttryck för tidens hälsoiver. Han var uppenbarligen förtjust i de möjligheter som Biskra erbjöd i form av en varierad kost, så till den grad att han efter ett besök på torget skickar $5 \mathrm{~kg}$ dadlar till Onni Okkonen:

"Olen lähettänyt sulle tämän maan antimia, tateleita, yhden viiden kilon laatikon ja toivon että ne saapuvat sulle kaikella kunnialla ja että ne on hyviä. Uskon kyllä tähän myyjään jolta ne ostin, että hän on laatikon täyttänyt samalla tavaralla jota antoi maistiaisiksi ja ne olivat hyviä." 57

[Jag har skickat dig detta lands jordliga gåvor [antimia], dadlar, en femkilos låda, och hoppas att de kommer fram med hedern i behåll och att de är goda. Jag tror nog på den försäljare av vilken jag köpte dem, att han har fyllt lådan med samma vara som han lät mig smaka på, och de var goda.]

\section{Typer och exotik - mötet med det främmande}

Under sin relativt långa vistelse i Biskra fascinerades Rissanen enligt Clara Stocker av arablivet, basarerna, karavanerna, och sanddynerna i öknen. Han blev bekant bl.a. 
med en arabgosse, som han använde som modell för flera skisser. ${ }^{58}$

Rissanens Biskrabilder förställer främst olika arabiska typer och några teckningar av dromedarer, men inga från den karga öknen eller från andra ökenstäder i relativ närhet till Biskra. Huruvida Rissanen besökte andra platser är oklart, men en så pass lång vistelse skulle åtminstone teoretiskt ge utrymme för exkursioner ut i öknen. Ett stort antal franska postkort med motiv från ökenstäder som Touggourt och Bou Saâda har publicerats, vilket betyder att också de var eftertraktade resmål bland utlänningar. ${ }^{59}$ En fingervisning om att Rissanen de facto företog resor utanför Biskra är att han i intervjun $\mathrm{i}$ Konstrevyn nämner att det var "den stad där jag bodde längst", ${ }^{60}$ men jag har inte kunnat utreda huruvida han besökte andra platser än Biskra, även om det är sannolikt. I reportaget i Konstrevyn berättar han vidare att det är bäst att inte stanna i städerna utan ge sig av inåt landet där man också hittar de tacksammaste motiven. ${ }^{61}$

Rissanens bevarade Biskrabilder består av flera typporträtt av lokalbefolkningen: några mansprofiler i akvarell, en yngling $\mathrm{i}$ fez, och en kvinna i helfigur med en slän- da. Några schematiska, enkla teckningar har motiv som en sittande arabisk man, en arab på ett kafé, en på marken sittande man med ett par figurer i bakgrunden, och en enkel gruppstudie av arabiska män i olika ställningar, samtliga iklädda typiska, fotsida arabiska dräkter. Därtill förekommer ett antal teckningar av dromedarer. Rissanens har även skisserat upp en stadsvy, signerad "Najlikatu, Juho Rissanen Biskra 1931", som diskuteras längre fram i artikeln.

Väl i Biskra möter Rissanen något som för honom är helt nytt och främmande. Hans första reaktion var att nyfiket betrakta "den här avkroken av världen": "Täällä minä nyt töllistelen tätä maailman kulmaa"62:

"Täällä minä nyt olen, täällä niin sanottujen Murjaanien maassa, vaikka eihän nämä ole niin mustia kun näistä sanotaan. - Olen kyllä tavannut jo jotakuinkin mustan mutta ihan sitä pikimustaa en ole vielä saanut käsiini, ehken senkin pijan tapaan." ${ }^{\prime 3}$

[Här är jag nu, i det så kallade Morernas land, fast inte är de här alls så svarta som man säger om dem. - Jag har nog träffat en någotsånär svart men den riktigt becksvarta har jag inte ännu fått tag på, men månne inte jag snart träffar även en sådan.]

Rissanen åkte till Algeriet via Tunisien, ${ }^{64}$ sannolikt med ångfartyg från Marseilles, ett ofta anlitat fortskaffningsmedel. I mitten av december 1930 skickar han ett postkort från Tunis till Eemil Suihko, och berättar att han om några dagar ska resa vidare till Biskra, "paahtamaan nahkani aina Huhtikuulle" (grilla mitt skinn ända fram till April). ${ }^{65}$ Några veckor senare, väl framme i Biskra, skriver han till Onni Okkonen:

"Kyllähän täällä olis maalarille tekemistä tästä elämästä paljonkin, vaan en tiedä kuinka paljon kerkiän siitä maalata kun mulla on päätyöni, joka ottaa vielä pitkän aikaa vaan koitan kuitenkin kahmaista jotakin, niin paljon kun se on mahdollista." 60

[Nog skulle det finnas mycket att göra på denna plats för en målare av det här livet, men jag vet inte hur mycket jag hinner måla av det nu när jag har mitt huvudarbete, som ännu tar lång tid, men jag försöker grabba tag i någonting, să mycket som det är möjligt.]

Med huvudarbete avser han glasmålningarna för Finlands bank, som var hans sista större verk för hemlandet. Skisserna blev färdiga 1931, och fönstren installerades $1933{ }^{67}$ Clara Stocker framhåller att han i dem var trogen sitt finska konstnärslynne, även om "hans öga hade mött öknen och dess invånares säregna förtrollning". 68

Intervjun i Konstrevyn är full av samtidens stereotypier gällande hur man såg på Nord- 


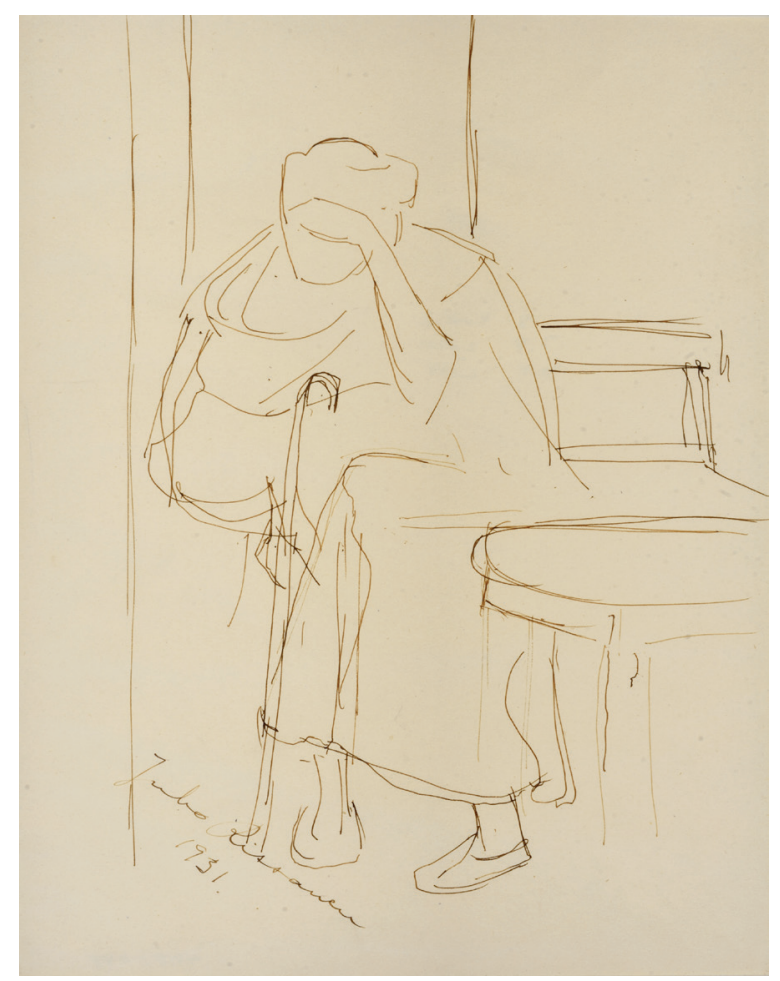

Bild 5. Juho Rissanen, Vilande man (arab), 1931. Tusch, $34,5 \times 25$ cm. Kuopion Kulttuurihistoriallinen museo, dep. Kuopion

afrika, på "orienten": här får vi läsa om magdans, dromedarer och ökenlandskap. I intervjun berättar Rissanen att han träffade på en hel del "typer" i Biskra:

"Typer finns det ju gott om där nere och särskilt bland nomaderna påträffar man många intressanta sådana. De bo i tält som egentligen bara är en trasa upphängd på en käpp och nakna är de både sommar och vinter och jag kan inte förstå hur de härdar ut med livet" ”

Många av de Biskrabilder av Rissanen som granskas här är enkla teckningar och akvareller föreställande lokala typer. De fles-

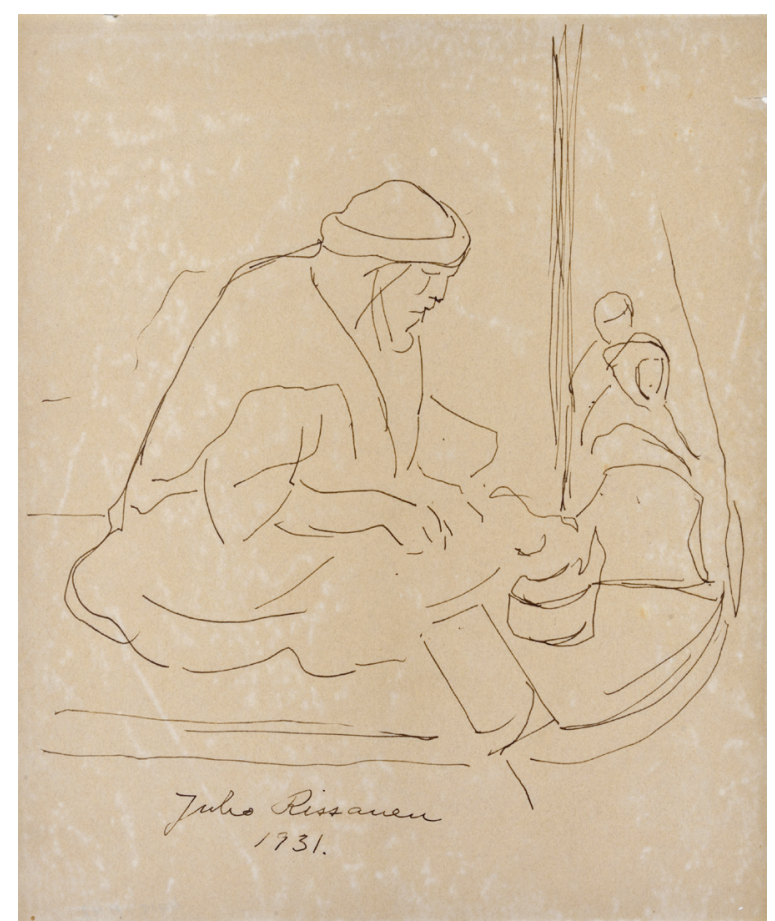

Bild 6. Juho Rissanen, Sittande man (arab), 1931. Tusch, $29,5 \times 25,5 \mathrm{~cm}$. Kuopion Kulttuurihistoriallinen museo, dep. Kuopion taidemuseo (4418 A 47). ta teckningarna är snabba, schematiska, men männens klädedräkter är klart urskiljbara (Bild 5-7). Bildernas träffsäkra, enkla linjeföring för tankarna till Henri Matisses delikata teckningar; intressant nog har också Matisse vistats i Nordafrika, 1906 i Algeriet inklusive Biskra, och senare i Marocko 1912-13, men hans bilder därifrån består främst av studier av dräkter, blomster i granna färger och stadslandskap, helt olikt Rissanens Biskrabilder. Det samma gäller för andra europeiska modernister som vistades i de orientaliska länderna i början av 1900-talet. ${ }^{70}$ Och Rissanen var de

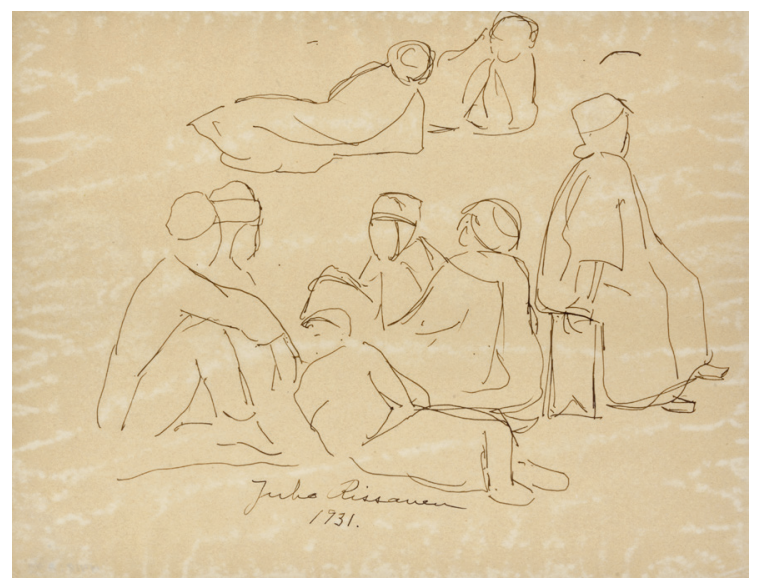

Bild 7. Juho Rissanen, Sittande män (araber), 1931. Tusch, 25,6 x 33,5 cm. Kuopion Kulttuurihistoriallinen museo, dep. Kuopion taidemuseo (4418 A 49). 


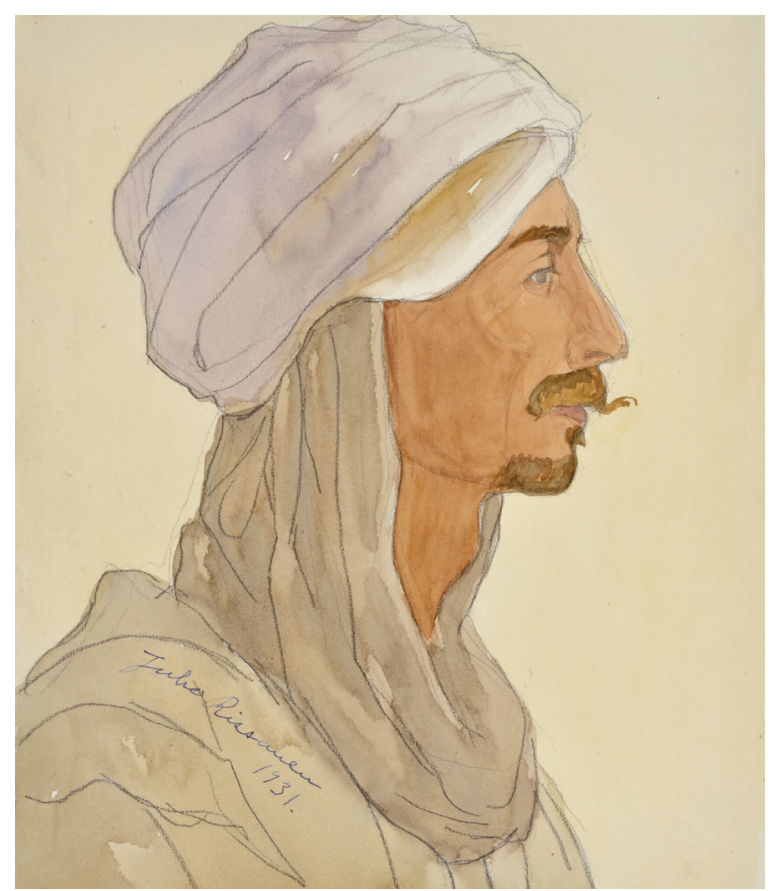

Bild 8. Juho Rissanen, Arabiskt manshuvud, 1931. Akvarell, $38 \times 31 \mathrm{~cm}$. Kuopion Kulttuurihistoriallinen museo, dep. Kuopion taidemuseo (3070/3).

facto en "linjekonstnär" redan i tidiga år, ${ }^{71}$ vilket kommer bra till uttryck även i hans betydligt senare linjeteckningar från Biskra.

Rissanen har även avbildat arabiska män i två akvareller (Bild 8-9). Dessa akvareller skildrar männen i profil och med arabisk hu-

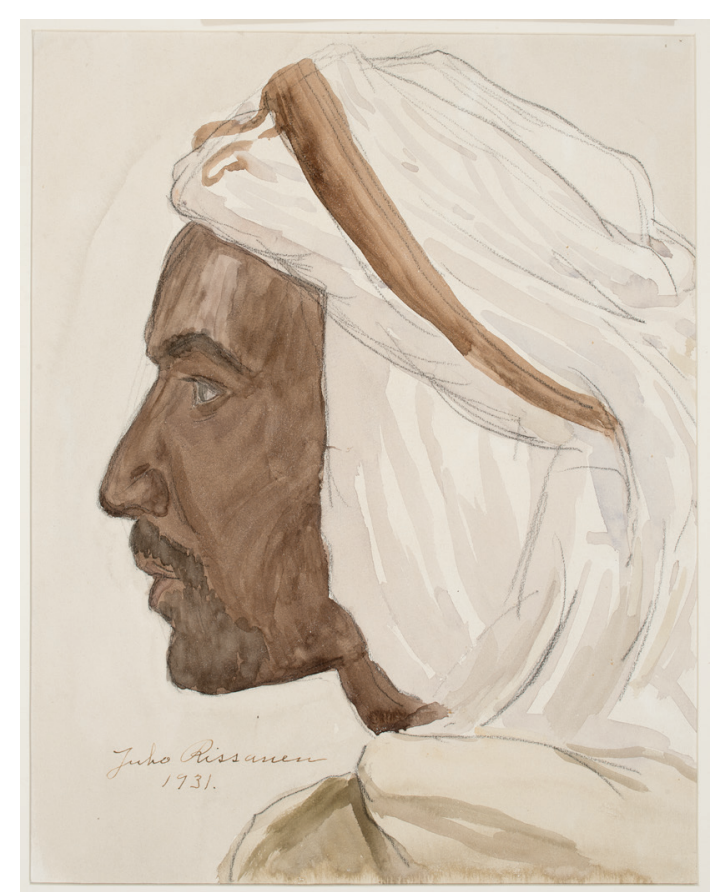

Bild 9. Juho Rissanen, Manshuvud (arab), 1931. Blyerts och akvarell, $37 \mathrm{x}$ $29 \mathrm{~cm}$. Åbo Konstmuseum (Foto: Vesa Aaltonen).

vudduk, och är i utförandet mer exakta än i hans teckningar. Han har också målat en yngling iklädd en karakteristisk röd, arabisk huvudbonad, en fez (Bild 10). Dessa bilder visar på ett djupare intresse för det exotiska just på grund av att de är med omsorg
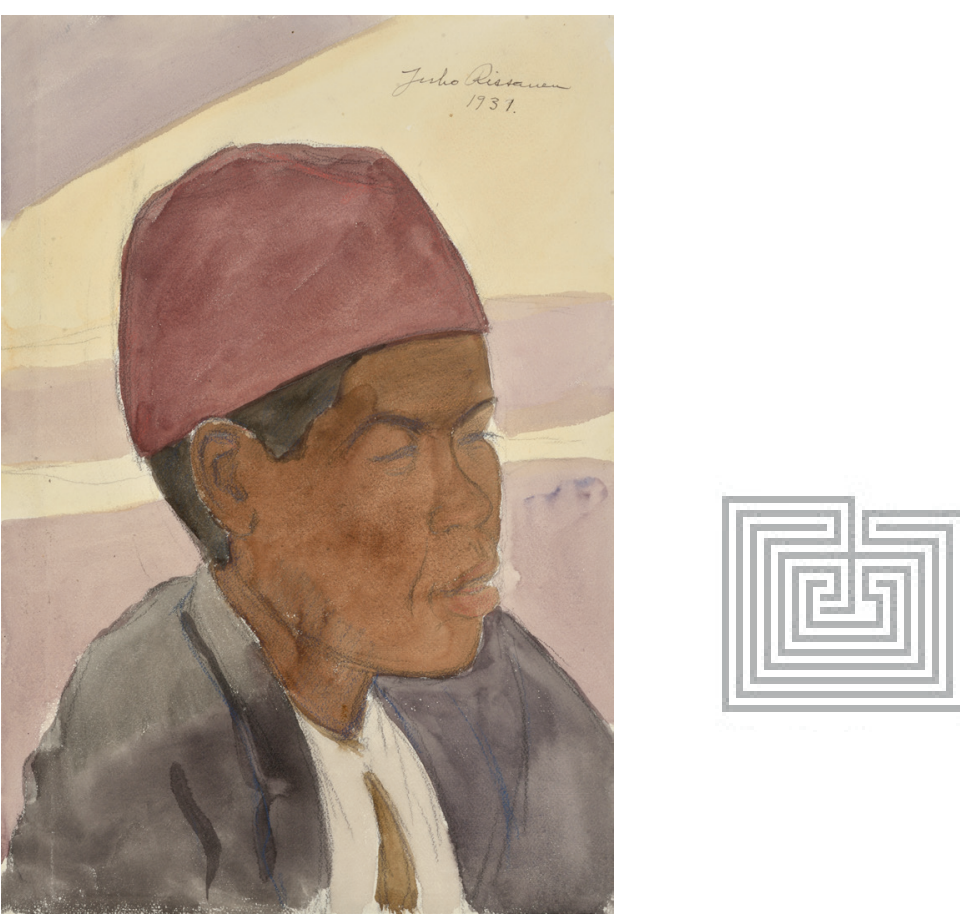

Bild 10. Juho Rissanen, Mörkhyad man i fez, 1931. Akvarell, 43 x 29. Kuopion Kulttuurihistoriallinen museo, dep. Kuopion taidemuseo (3070/2).

målade typporträtt. Också många av hans postkort föreställer arabiska typer, bland annat en sittande man i arabisk dräkt, vid en husvägg (Bild 11: Biskra - Arabe tricottant), ${ }^{72}$ och ett av en man som tränar falkar (Biskra - Fauconnier). ${ }^{73}$ Bland de franska postkorten 


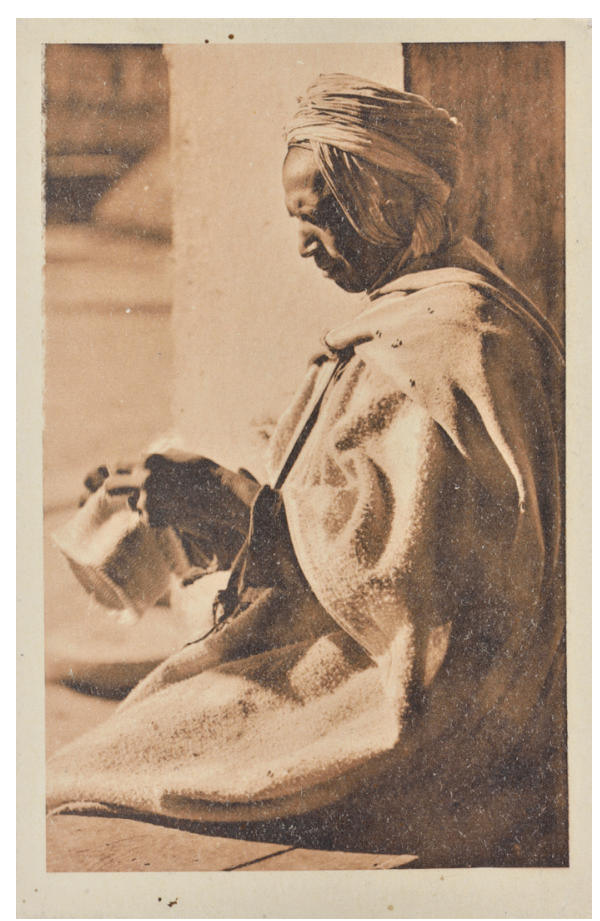

Bild 11. Biskra. Arabe tricottant. Postkort skickat av Rissanen till Eemil Suihko, Hotel du Sahara, Biskra Algerie, 12.3.1931. Kuopion taidemuseo/Kuopion isänmaallinen arkisto.

till Onni Okkonen hittar vi en bild av en berberkvinna, och ett av en flicka bärande ett vattenkrus. $^{74}$

Vidare är speciellt kvinnan i helfigur som spinner på en slända intressant Bild 12), precis samma typ förekommer även i ett av

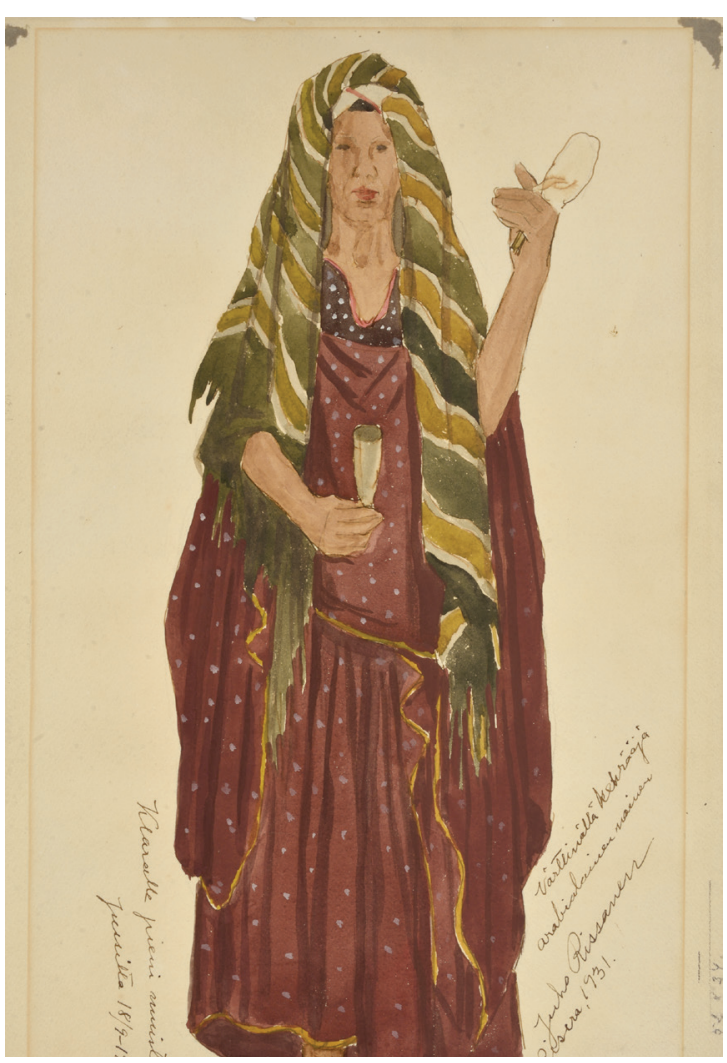

Bild 12. Juho Rissanen, Arabisk kvinna som spinner på en slända, 1931. Akvarell, $42,5 \times 25$. Kuopion Kulttuurihistoriallinen museo, dep. Kuopion taidemuseo (4418 A 22).

fotografierna i Lundhs reseskildring (Bild 13). Lundh berättar: "Långt ut mot öknen [vid Sidi Okba], där den höga muren trollas bort och där skuggan av en bågnande portgång är det

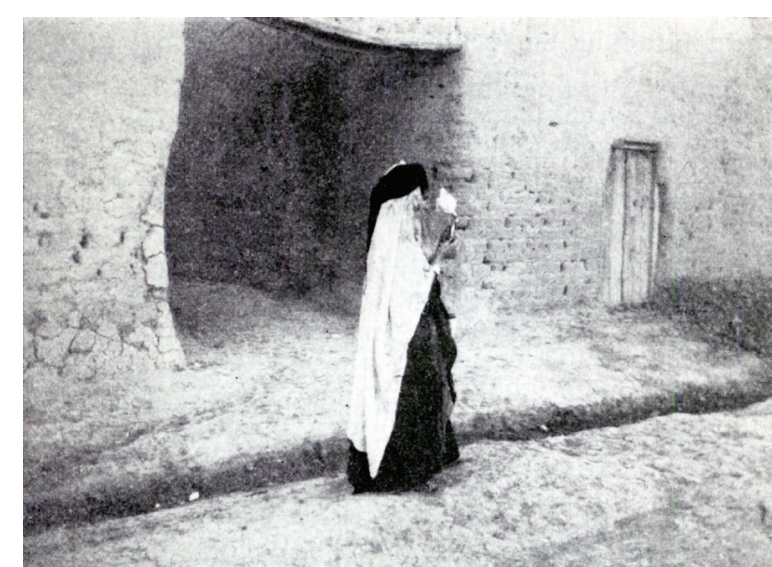

Bild 13. Kvinnan med sländan, Lundh 55.

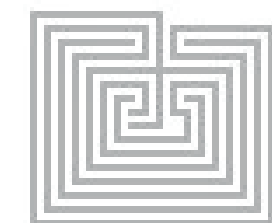

enda påtagliga, trädde en kvinna med slända ut som själva féen i sagan. Hon såg ej åt höger eller vänster, hon gick sakta förbi med sländan, och alla veko undan för henne."75 Kvinnan i fotografiet, liksom i Rissanens bild, har fotsida kläder och en lång huvudduk som räcker långt ned på ryggen, ned mot vaderna. Här har han intresserat sig för kvinnans färggranna dräkt och lokalt hantverk.

Rissanen intresserade sig även för exotiska djur, närmare bestämt kameler (dromedarer). I sammanhanget är framför allt ett postkort som han skickat till Eemil Suhko och som föreställer en arab sittande på kamelryggen intressant. Titeln på baksidan lyder 


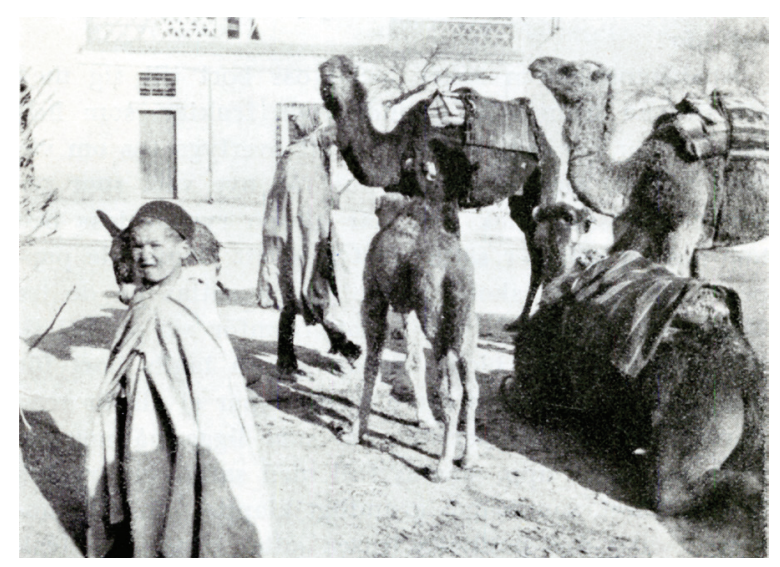

Bild 14. Biskra: Kameler att hyra, Lundh 45.

Env. De Biskra. Un Chamelier. På framsidan längs kanten av postkortet har Rissanen skrivit: " Kohta minäkin menen tällälailla ajamaan hiekka[-]aavikolle" - "Snart åker också jag på detta vis ut i sandöknen" (se bild 1). ${ }^{76}$ Allt tyder på att Rissanen var väl medveten om att i Biskra kunde man hyra kamel för exkursioner ut i öknen! Detta är ytterligare en självklar del av Biskrapaketet; Lundh noterar att Biskra är den bästa utgångspunkten för ökenfärder". ${ }^{77}$ (Bild 14). Påtagligt många av de postkort Rissanen använde som brevpapper föreställer dromedarer, den typ av "kameler" (chameaux) som förekom i Algeriet (Bild 15: Scènes et Types. Tétes
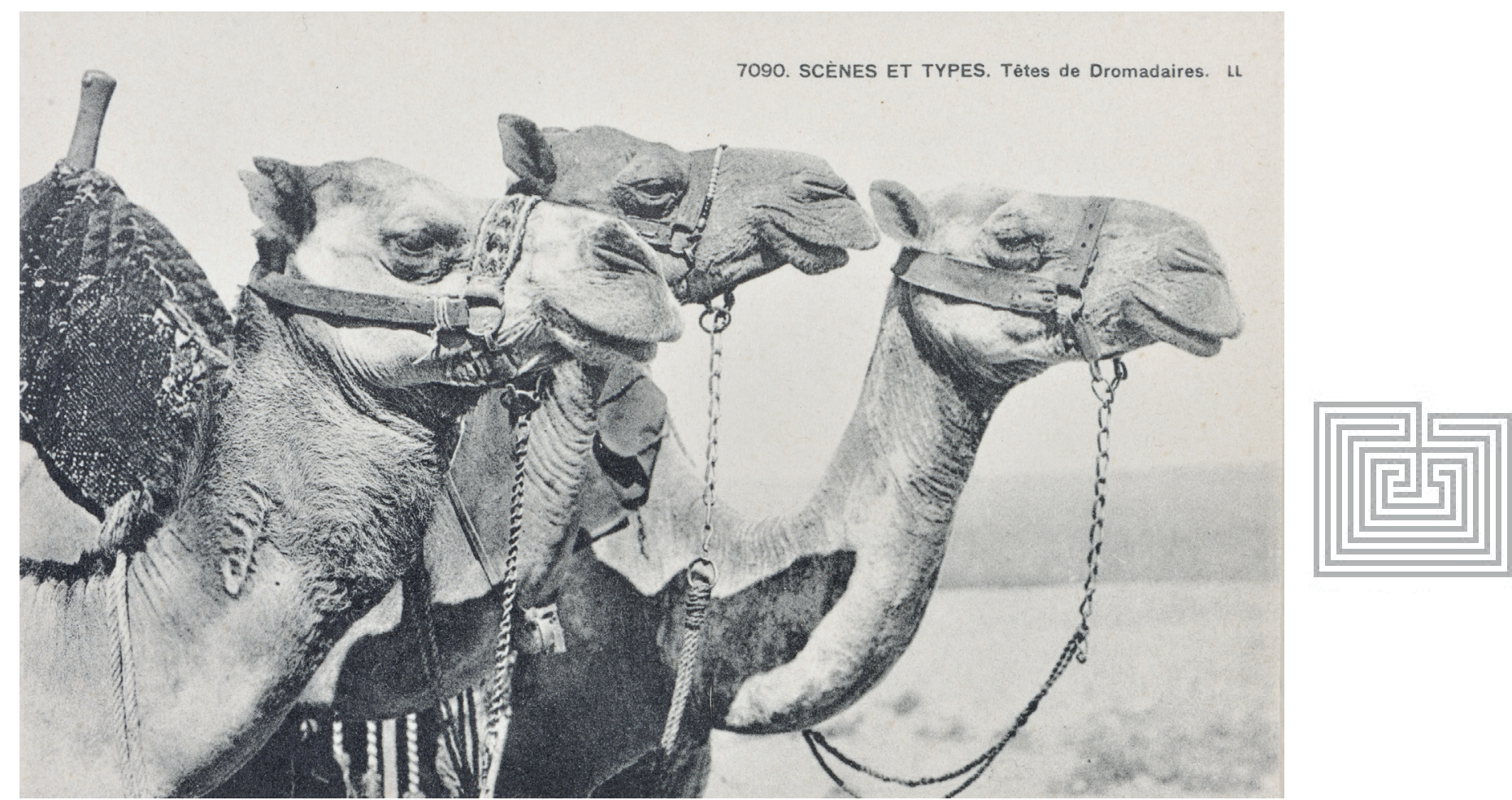

Bild 15. Scènes et Types. Tétes de Dromadaires. Postkort skickat av Rissanen till Eemil Suihko, Hotel du Sahara, Biskra Algerie, 12.2.1931. Kuopion taidemuseo/Kuopion isänmaallinen arkisto.

de Dromadaires). ${ }^{78}$ Ett annat postkort har liknande ökenmotiv, det föreställer två män i arabisk dräkt som leder varsin dromedar genom sanddynerna (Biskra - Passage des Dunes de Sable). ${ }^{79}$ Ytterligare ett visar även det två dromedarer i stenöknen (Départ de
l'Oasis), ${ }^{80}$ ett annat föreställer två ryttare vid sanddynerna; kortet har liksom de andra en fransk rubrik (Scènes et Types - Méharistes travesant [sic.] les dunes). ${ }^{81}$ Ytterligare ett postkort föreställer en karavan (Une Caravane). ${ }^{82}$ 


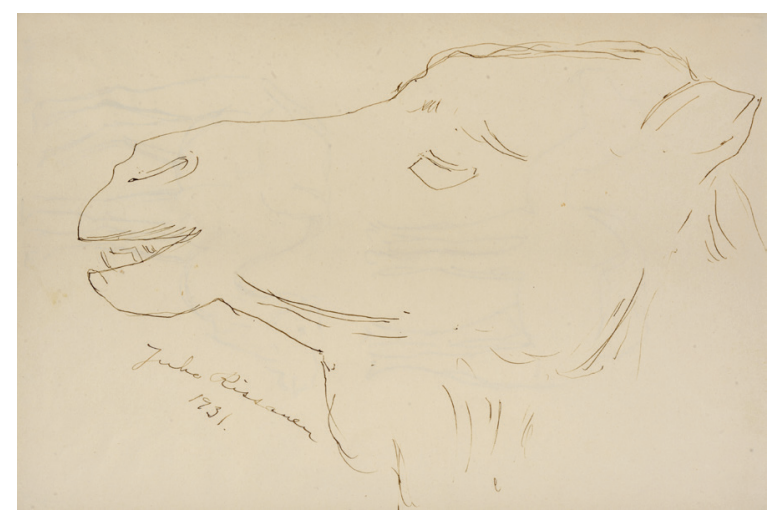

Bild 16. Juho Rissanen, Kamelhuvud, 1931. Tusch, $25 \times 35,3 \mathrm{~cm}$. Kuopion Kulttuurihistoriallinen museo, dep. Kuopion taidemuseo (4418 A 50).

Det är därför inte överraskande att det bland Rissanens bilder förekommer några enkla teckningar av dromedarer, vilket visar att han anammat det exotiska (Bild 1618). Resenärer i Biskra fascinerades av vad man kan kalla ett slags kamelturism, riktad till västerländska besökare. Enligt Luc Georget blev just kamelen, men även kamelryttare och karavaner, som följd av den franska 1800-talsorientalismens skildringar en del av Orientens ikonografi och en symbol för Sahara; det är det mest seglivade motivet inom orientalismen, populärt långt in på

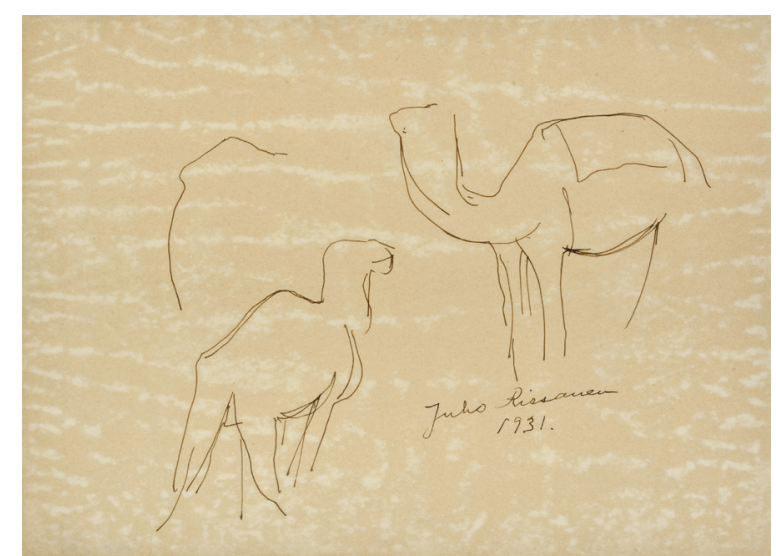

Bild 17. Juho Rissanen, Två kameler, 1931. Tusch, 25,5 x 33,5 cm. Kuopion Kulttuurihistoriallinen museo, dep. Kuopion taidemuseo (4418 A 46).

1900-talet. I både bilderna och reselitteraturen beskrivs Sahara som ett stort hav utan vatten. Om och om igen inspirerades orientalisterna av det flacka ökenlandskapet och en hel uppsjö av ökenbilder visades på utställningar hemma i Paris, både på Salongen och på Salon des Peintres Orientalistes. Den tomma, vidsträckta öknen ses både i rena landskapsbilder (ofta i panorama) och som bakgrund till genremotiv med beduiner och kameler i sandstorm, eller karavaner som stannat vid en oas. Kamelkaravaner avbildades ofta i profil mot en tom himmel. ${ }^{83}$ Även


Bild 18. Juho Rissanen, Tre kameler, 1931. Tusch. $35,2 \times 24,8 \mathrm{~cm}$. Kuopion Kulttuurihistoriallinen museo, dep. Kuopion taidemuseo (4418 A 45).

om Rissanens bilder som granskas i denna artikel är få, frapperas man av att det bland dem förekommer förhållandevis många kamelbilder, i form av både teckningar och som postkort. 


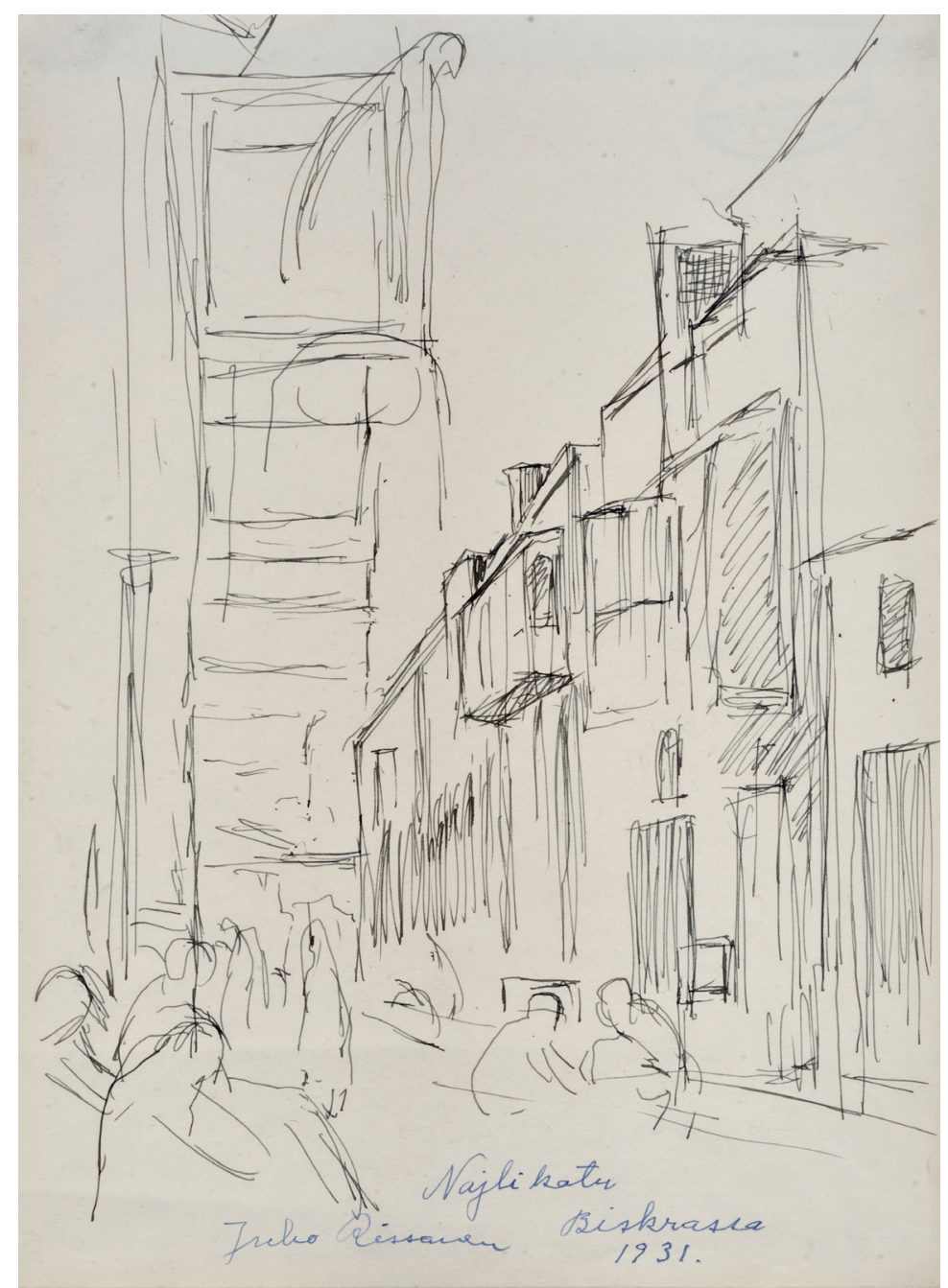

Bild 19. Juho Rissanen, Najlikatu, signerad "Najlikatu Biskrassa 1931". Tusch, 36 x 25,5 cm. Kuopion Kulttuurihistoriallinen museo, dep. Kuopion taidemuseo (dep. 4418 A 39).

\section{Ouled Naïl - österländsk dans}

Bland de Biskrabilder som behöver en närmare granskning är en snabb teckning av en gata med några skissartade figurer, signerad "Najlikatu Biskra 1931". Även om Rissanens teckning är mycket enkel, förstår man den bättre genom att betrakta det sammanhang inom vilket den tillkommit.

Såsom signeringen antyder, föreställer vyn den berömda gatan Rue Ouled Naïls, Rissanen har återgivit de balkonger som är typiska för gatan. De postkort som publicerats föreställer påfallande ofta just denna gata, bland annat hittar vi ett liknande postkort i Parviainens samling, som han har använt som förlaga till en teckning. ${ }^{84}$ "Najlikatu" passar bra in i det turistiska konceptet vad gäller bilden av Biskra som en exotisk stad.

Gatan har fått sitt namn efter berberstammen Ouled Naïls, en nomadstam från öknen mellan

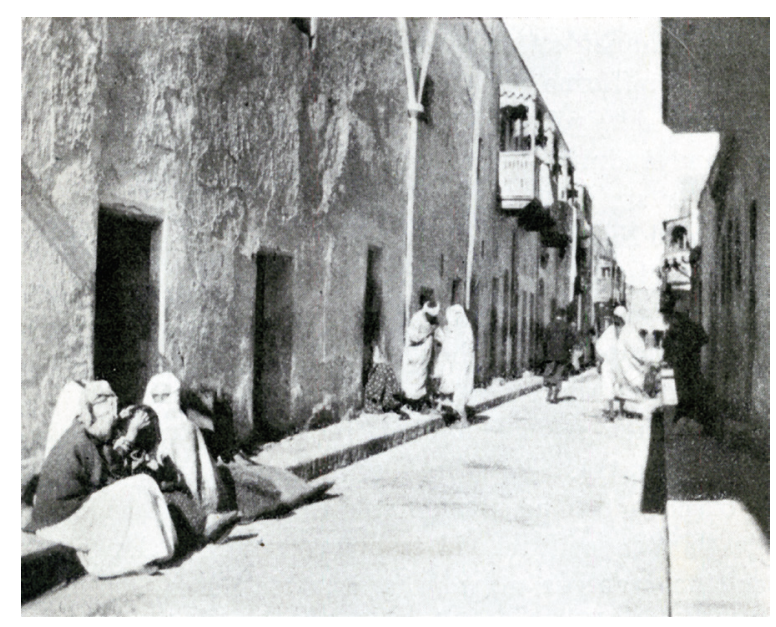

Bild 20. Biskra: Ouled Nail-gatan, Lundh, 31.

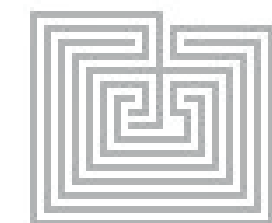

Bou Saâda och M'zab mot väst från Biskra. Det handlar om unga kvinnor som skickades till staden för att tjäna in sin hemgift genom att uppträda på kaféerna, framför allt på just denna gata. Här kunde man möta kvinnor som var vana att posera och kunde dansa utan slöja, eftersom det tilläts kvinnorna i stammen som levde enligt andra sociala normer än arabkvinnorna. Enligt Gareth Stanton blev Ouled Naïl-flickorna tidigt en turistattraktion, även för målande konstnärer. Redan 1897 beskriver en reseskildring hur vissa danserskor tog emot författare och konstnärer, vilka kunde betala för att använda dem som modell. ${ }^{85}$ Ett antal år senare, 1913, 


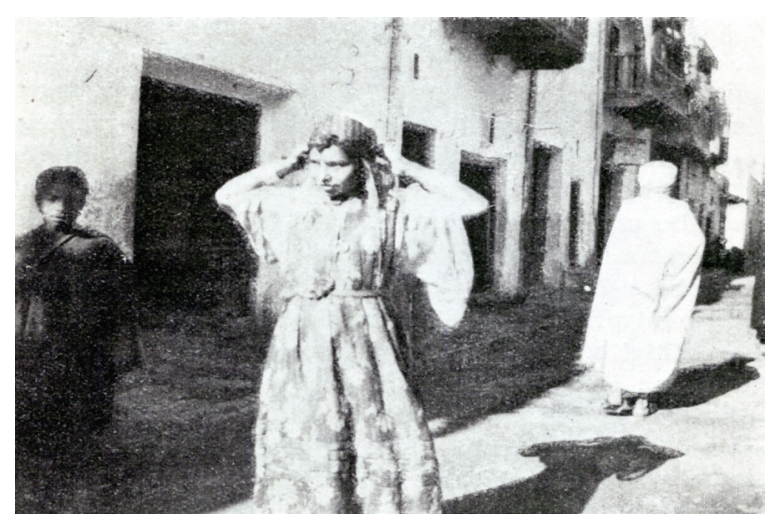

Bild 21. Ouled-Nail-flicka, Lundh 33.

skriver engelsmannen John F. Fraser om en fransk konstnär som anordnat en dansföreställning hemma hos sig i Biskra, och Fraser beskrev dansen som njutningsfull, obehindrad och passionerad. Vardagligt var flickorna kända som les naylettes och de var en vanlig syn i Biskra. ${ }^{86}$

Les naylettes och deras danser gjorde Biskra radikalt annorlunda än Europa. Även om vissa besökare hade ett relativt ambivalent förhållande till föreställningen och upplevde dansen som oanständig, var de flesta trollbundna. ${ }^{87}$ De beskrev dansen som enastående graciös, och var betagna av den överdådiga klädedräkten, juvelerna och andra smycken i silver och guld som flickorna vad draperade i. År 1927, dvs bara några år före Rissanens vistelse i staden, inkluderade den finländske författaren Armas Launis i sin reseskildring från Nordafrika och speciellt Biskra, en beskrivning av flickorna som långt motsvarar denna allmänna uppfattning av naylettes, han fäster sig speciellt vid deras med ansiktsfärg målade, obeslöjade ansikten, den färggranna klädedräkten och de broderade silkessjalarna samt överdådiga silver- och guldsmycken som klirrar i flera lager på armar och anklar. ${ }^{88}$

Även i Lunds reseskildring får vi en rätt så ingående skildring av gatan och dess flickor, avsnittet är illustrerat med flera av författarens fotografier. (Bild 21). På ett av fotografierna ser vi en flicka iklädd mönstrad klänning och huvudduk framför de karakteristiska balkongerna i bakgrunden. I motsats till Lundhs mer profana (och mer verklighetstrogna) fotografi porträtterar samtida professionella fotografer flickan som mycket sensuell och vacker. (Bild 22). Lundhs beskrivning är avslöjande med tanke på gatans attraktionskraft bland turisterna:

"I Ouled-Nails gator gå européerna om kvällen som i ett fredligt tivoli bland alla de tända små ljusen. Herrar och damer promenera helt trankilt bland araberna för att titta på de utställda, mer eller mindre skimrande prinsessorna, som i brist på skönhet alltid ha glitter nog och i blicken så pass mycket liv, att det stundom räcker till för två. De sitta i klungor på trapporna eller på tröskeln och ha alla en vaksam blick upp mot det lilla flämtande ljuset vid trappans avsats. ${ }^{89}$

Dansen blev således relativt tidigt en del av Biskrapaketet, eller som en cynisk krönikör skrev 1913, att alla går till Ouled Naïl-gatan där professionella kurtisaner uppträder, en smått anstötlig föreställning enligt krönikören. Han noterar hur västerländska damer promenerar och dricker kaffe bland feta naylettes som poserar i oanständiga ställningar. Naylettes ursäktar sig med att detta är en av deras sedvänjor, men skribenten misstänker att det bland de äkta berberflickorna förekommer även oäkta naylettes. De flesta flickorna är importerade från Alger eller Constantine för att underhålla turister från Europa och Amerika. Autenticiteten - om den ens funnits där - var inte längre central för dansupplevelsen, utan hade förvandlats till ett profitabelt spektakel ämnat för turister. ${ }^{90}$

Det är denna verklighet som möter Rissanen 1931. Av detta ser man dock ingenting i skissen från gatan, där figurerna är tecknade med endast vaga konturer. Intressantast i sammanhanget är att han upplevde stäm- 
ningen, dansen och miljön, även om det långt handlar om en iscensatt verklighet.

Vi vet alltså att Rissanen besökte den berömda gatan, men inga andra bilder därifrån har kunnat spåras. I intervjun med Rissanen i Konstrevyn 1931 berättar han om dansande flickor, och han syftar högst sannolikt på Ouled Naïls. Här framkommer även att han använt magdanserskor som modell; han berättar hur han fått köpslå om priset, som till en början var övermåttan högt men som snabbt sjönk efter att de hugade modellerna ropat ned priset. ${ }^{91}$ Enligt Clara Stockers berättelse erbjöd sig en modell att posera gratis, bara hon fick målningen i utbyte av konstnären. Rissanen lär då ha svarat att om han målar något så håller han nog målningen själv. Han skulle då ha stiftat bekantskap med just kvinnor utan slöja, vilket inte kan syfta på något annat än naylettes. ${ }^{92}$ Lite senare i intervjun i Konstrevyn berättar han dock att något som han aldrig lärde sig fatta:

"[...] var de små näpna magdanserskorna på kaféerna. Slanka, spâda flickor utan en tillstymmelse till fettlager eller något sådant, men alla med en mage som oupphörligt och taktfast hoppade upp och ned till musiken. Jag har aldrig i livet förstått att en människomage kan hoppa på det sättet. Flickorna stod för det

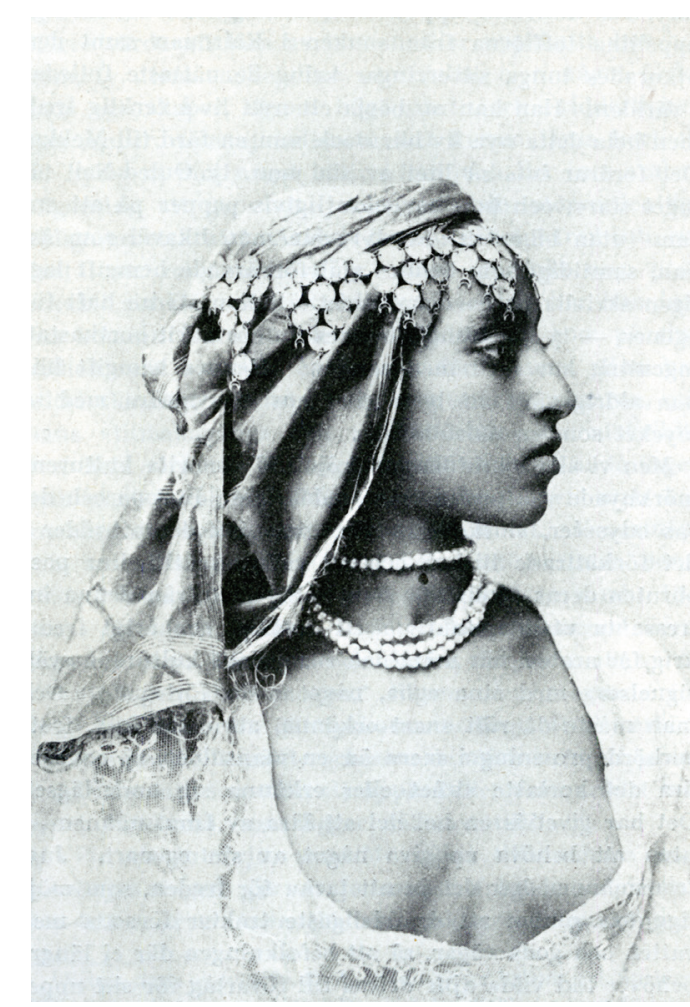

Bild 22. En Ouled-Nail-flicka, plansch, Lundh 35.

mesta alldeles stilla med ett orörligt ansikte och någon gång några få plastiska rörelser med $\mathrm{ar}^{-}$ marna eller benen, men magen - . Vackert livar det just inte, men egendomligt och obegrip ${ }^{8}$ Och naturligtvis en stor turistattraktion. ${ }^{93}$

\section{I kolonialismens fotspår}

Rötterna till vad man kan kalla den ökenturism som även Rissanen var delaktig $\mathrm{i}$ har gamla anor, de hittas redan i den tidiga orientalismens ökenskildringar och allt vad det innebär, men framför allt genom kopplingen till kolonialismen. En förutsättning för att orientalistisk konst kunde produceras överhuvudtaget var den franska kolonialmaktens närvaro i Algeriet och närheten till Sahara. Många av de tidiga orientalisternas motiv föreställer just den algeriska öknen som utlänningar fick tillträde till tack vare landets ställning som koloni. Här intar Biskra en speciell plats på grund av dess placering vid gränsen där det bördiga landet i norr övergår i karg öken, som upptar största delen av Algeriets areal. Åtskilliga av de orientalistiska målningarna bottnar således i en uttryckligen algerisk motivkrets. ${ }^{94}$

Då man granskar Rissanens Biskrabilder kan den koloniala aspekten inte förbises. Dioraman och panoraman som visades i Paris förmedlade ett kolonialt perspektiv till betraktaren av den konst som presenterades på stora massutställningar som Salon des Peintres Orientalistes. I inledningsfasen bekostade kolonialministeriet (de franska) konstnärernas resor och omvandlade det exotiska till en lekfull attraktion som samtidigt var en form av propaganda. Ända från slutet av 
1800-talet fram till Rissanens tid i Algeriet på 1930-talet präglas tiden av ett slags kolonial sociologi. Den franska närvaron i Algeriet var inte enbart en förutsättning för att orientalistisk konst kunde produceras; det orientalistiska konceptet harmoniserar med hur vi tänker om Det Andra i enlighet med dåtidens koloniala teori och historia. Den berättar lika mycket om Algeriet som om europén. De många utställningarna i Paris med orientalistiska ämnen omskrevs även i dagspressen - enligt Roger Benjamin är både utställningarna och recensionerna otaliga.$^{95}$ Utställningarna i Paris, där de franska kolonierna inklusive Algeriet presenterades, bidrog till att intresset för ökenlandet och dylika motiv ökade i antal och spreds. ${ }^{96}$ Som aktiv konstnär i Paris är det mer än troligt att Rissanen stiftat bekantskap med både utställningarna och kritiken, och den vägen fått information om den franska kolonin.

Som representanter för den orientalistiska genren räknas konstnärer som inte nödvändigtvis hade samma stil men som målade liknande motiv: haremsmiljöer, magdanserskor, typporträtt, arabiska härskare och ryttare, bilder av kamelkaravaner, ökenbilder, oaser, exotiska djur samt arabiska byggnader och stadsvyer från de så kallade orientaliska länderna. Dessa omfattar allt från Andalusien i södra Spanien över Nordafrika och Egypten till Turkiet och Grekland, de "bibliska" länderna inräknade, det vill säga länder som hör eller har hört till den islamska kultursfären. Orientalismen hade sin glansperiod under 1800-talet, men fortsatte långt in på 1900-talet - speciellt de finländska orientalisternas resor och målningar placerar sig inom den sena 1900-talsorientalismen. ${ }^{97}$

Till denna grupp räknas även Juho Rissanen, som blir en del av den senare generationen orientalister som upprepar och befäster den i väst etablerade bilden av ökenlandet. Den sena orientalismen bygger på samma motivkrets, men uttryckssättet är ett annat; man frapperas dock av att motiven, även om de tillkommit långt senare, $\mathrm{i}$ stort har samma repertoar och seglivade stereotyper. Rissanens nordafrikanska bilder är således sena uttryck för den orientalistiska genren och fransk kolonialism. Han kände bra till den orientalistiska bildrepertoaren, vilket blir speciellt tydligt i de många postkorten med lokala motiv som han använde som brevpapper; de är bra indikatorer på vad som avsågs vara det främmande, det annor- lunda och det exotiska, vilket har ett direkt samband med den franska kolonialmakten. Det är uppenbart att den franska, seglivade 1800-talsorientalismen inverkade på valet av motiv. Sammantaget utgör Rissanens Biskrabilder - tillsammans med postkorten - ett representativt genomsnitt av de motiv som var vanliga för orientalisterna och framför allt de som präglade hur man uppfattade Biskra och Sahara.

Och även om Rissanens teckningar och akvareller är få till antalet, berättar de mycket om honom som turist. Han upplevde österländsk dans på Ouled Naïl, ett spektakel som med tiden blivit allt mer en turistattraktion, och tecknade en snabb skiss av gatan. Och även om det i materialet inte finns teckningar av danserskor använde han sig enligt intervjun i Konstrevyn av modell. Vidare är typporträtten av lokalbefolkningen helt i linje med den orientalistiska bildrepertoaren, liksom motiven i samtida fotografier och turistvykort. Rissanens postkort inkluderar även bilder av dromedarer i öknen - också det en turistattraktion - vilket resulterade $\mathrm{i}$ Rissanens dromedarskisser, även om det inte finns några ökenbilder bland de bilder som granskats här. De vykort han väljer visar 
på hans koloniala beteende - utgående från de franska titlarna på postkorten och annoteringar om ateljéer var de framställda av franska fotografer som var stationerade i Alger. ${ }^{98}$ Under sin tid i Biskra gick Rissanen således i andra konstnärers och turisters fotspår.

En intressant aspekt värd att nämna är att den västerländska närvaron i Biskra är frånvarande både $\mathrm{i}$ orientalisternas bilder och $\mathrm{i}$ postkortens motiv, liksom i Rissanens bilder. Detta är nämnvärt eftersom det ju handlar om en stad som var full av främlingar. Inget av den städse närvarande turismen är synlig i bilderna, varken i postkorten eller i Rissanens teckningar. Det samma gäller Lundhs illustrationer, fotografier som han enligt utsago tagit själv. Rissanen skildrar en annan kultur, men en kultur som redan vid tiden för hans besök genomgått en tydlig förändring och modernisering. Såsom framkommer i intervjun i Konstrevyn, var han en parisare bland andra. Biskrabildernas exotiska motiv är i linje med den franska kolonialmaktens propagandabilder och visuella kultur, och det var mer eller mindre förutbestämt vad som var intressant.

Orientalismen har således en lång (fransk) historia med många dimensioner. Det har även Biskra; mycket vatten hade dock runnit under bron vid Rissanens besök, och staden hade genomgått en betydande omvandling från de tidiga åren av turism. Redan 1913 skrev John F. Fraser att Biskra för många år sedan "doftade av Orienten", att staden sannerligen var arabisk. Sedan byggde fransmännen järnvägen, så att det blev lätt att ta sig dit, och så upptäckte läkarna att luften var så torr att staden var just den rätta platsen för invalider. Till slut, konstaterar Fraser, skrev Mr Hitchen sin roman The Garden of Allah, och så var skadan skedd. Enligt Fraser är det Mr Hitchen som är den egentliga skaparen av den bild av Biskra man hade då, vilket hämtade mycket guld till staden. Men Fraser hade önskat att The Garden of Allah aldrig hade blivit skriven, för Biskra var förstörd, ofrånkomligen förstörd. Staden hade blivit en helgedom för den galopperande turisten, här idag och borta i övermorgon. Östern kvävdes av väst. Istället för en naturlig stad hade Biskra blivit en förfalskat österländsk stad. ${ }^{99}$

Men Biskras rykte levde kvar hos utlänningarna, även om västerniseringen till sist ledde till att staden blev allt mindre attraktiv för den seriöse turisten; just de tekniska innovationerna som inledningsvis hade bidragit till dess popularitet, tillsammans med dess mystik, gjorde att staden förlorade något autentiskt. Men samtidigt var det inget som försvann i ett slag, regionens koloniala historia bidrog till att turisterna länge fortsatte att resa dit, även så sent som Rissanen gjorde. Turisterna fastnade i Biskra för vad man kan kalla arkaiskhet, ett slags permanent och kvardröjande (öken)romantik. I det avseendet var staden med omnejder en av orientalismens utsiktspunkter långt in på 1900-talet.

Trots att Orientalismen som genre varit hårt kritiserad redan under sin glansperiod på 1800-talet, har många välkända målare använt sig av orientalistiska motiv i sin konst, de har rest till just Biskra $i$ jakt på inspiration: Renoir, Matisse och Klee. ${ }^{100}$ Hur många känner idag till att Renoir varit i Biskra och låtit sig inspireras redan 1880-1881? Även Matisses första nordafrikanska resa till Biskra 1906 har fallit i glömska, speciellt eftersom den lämnade så få spår i hans konst. Hundratals både kända och mindre kända konstnärer besökte Nordafrika, både under 1800-talet och senare under 1900-talets första decennier; Roger Benjamin räknar upp ett stort antal franska målare och skulptörer som besökte uttryckligen Biskra. Han näm- 
ner dock att det för dessa ofta var "omöjligt" att måla där - att de inte förmådde - mycket på grund av att stadens glansperiod redan var förbi; Biskra var inte längre öknens drottning, höljd i mystik. ${ }^{101}$

Det verkar som om detta drabbat också Rissanen, som visserligen skriver att där skulle finnas mycket för en målare att skildra, men hans produktion från Algeriet är anspråkslös. Det är nästan för lätt att dra slutsatsen att hans här granskade algeriska bilder avviker bjärt från hans övriga produktion; hans mest ansedda målningar är ju skildringar av det finska folket. Men på ett ideologiskt plan skiljer de sig inte så mycket från hans inhemska allmogebilder, i bådadera eftersträvar han att skildra det karakteristiska hos "ursprungsbefolkningen". Det samma gäller de postkort han köpte och skickade som brev till hemlandet; de är ypperliga indikatorer på vad han upplevde som säreget. Men som skisserats ovan, hade Biskra förvandlats från att ha varit en Orientens pärla vid öknens rand till att bli en turisthåla. Det sena årtalet för Rissanens vistelse gör att man nog kan anse att den var - precis som det framkommer i hans brev uttryckligen en turist- och hälsoresa. Hans snabba skisser och akvareller fungerar mer eller mindre som souvenirer, minnen efter en efemär upplevelse, och saknar betydelse för hans samtida och senare produktion, vilket diskuteras närmare i det följande.

\section{Ingen plats för det främmande - Rissanen} och konstens kanon

Till sist några ord om Rissanens konst främst på 1920- och 1930-talen. Den bild man får av konstnären genom att granska hans Biskraresa och hans nordafrikanska bilder avviker starkt mot den kanoniserade variant som vi hittar i forskningslitteraturen, där konstnären för det mesta porträtteras som en grovbarkad målare av det finska folket. ${ }^{102} \mathrm{Hans}$ bilder med inhemska motiv är de som gått vidare $\mathrm{i}$ konsthistorien, medan hans sena produktion inte beaktas i samma utsträckning, förutom hans monumentalmåleri och glasmålningar, båda med inhemska, mer patriotiska motiv. Det samma gäller hans Biskraperiod som ibland omnämns med en rad eller två i en del av forskningslitteraturen, dock utan närmare analys.

Under tidsperioden 1920- och 1930-talen befann Rissanen sig för det mesta i utlandet, främst i Europa, före den definitiva flytten till
USA. Han fortsatte att ställa ut i Finland, men hans konst från den här tiden väckte inget större intresse i dagspressen. Utgående från det man kan läsa om Rissanen i finländsk konstkritik noteras hans deltagande i (grupp) utställningar, men hans konst behandlas inte i detalj. Vidare har jag inte hittat ett enda exempel där han explicit skulle ställa ut Biskrabilder. ${ }^{103}$ En sannolik förklaring till detta förbiseende är tidens nationalistiska vindar, som troligtvis bidragit till att det utländska inslaget i Rissanens senare produktion inte erkänts, utan snarare nedvärderats. En annan förklaring är att Biskra inte upplevdes som så exotiskt som tidigare: vilken seriös resenär låter sig frapperas av det organiserade nöjesresande som förkroppsligas i Biskraturismen? Åtminstone förekommer Rissanens nordafrikanska bilder varken på utställningarna eller i dagskritiken.

Rissanens minnesutställning lät vänta på sig, sannolikt på grund av att han bott så långa perioder utomlands; trots att konstnären avled redan 1950 (bosatt i Florida), ordnades den först 1956 i Helsingfors konsthall. Presentationen av konstnären är författad av den finländske konsthistorikern Sakari Saarikivi, texten är koncentrerad till Rissanens 
karriär som bondeskildrare kring sekelskiftet 1900. Efter det företog Rissanen, enligt Saarikivi, "konstnärliga irrfärder", det vill säga studerade freskoteknik i Italien, bekantade sig med de franska postimpressionisterna, deltog i Septems och Novembergruppens "strävanden", samt fick många beställningsarbeten, både för oljemålningar, vägg- och glasmålningar. Men, skriver Saarikivi:

"I och med att [Rissanen] inträdde i det internationella konstlivets virvlar, förlorade han det viktigaste - förmågan att koncentrera sig på ett enkelt uttryckssätt, som hade sitt ur sprung $i$ hans egen natur. Endast några få av de senare årens verk når samma nivå som hans första arbeten och inte ett enda av dem skulle utan I890-talets verk garantera Rissanen den ledande plats, som han onekligen är berättigad till inom vår konst.” ${ }^{\circ} 4$

Vad gäller Rissanens Floridavistelse skriver Saarikivi att underrättelserna därifrån var nedslående, och att de arbeten han utförde där inte var "hans namn värdiga". ${ }^{105}$ Under tiden före Floridavistelsen ställde han visserligen ut också i Finland, i bland annat ett odaterat katalogblad hittar vi verknamn som antyder att utställningen ägde rum under hans "europeiska" period på 1920-talet; bilderna har motiv från bl.a. Martigues, Bretagne, St. Germain-en-Layé, Marseilles, och
Spanien. ${ }^{106}$ Däremot uppmärksammades dessa utställningar inte i den inhemska utställningskritiken i någon nämnvärd utsträckning. ${ }^{107}$

På utställningen i konsthallen 1956 visades verk främst från privata samlingar, även om några hör till museisamlingar, företrädesvis Ateneum. Av de 98 utställda numren är endast tio från 1920- och 1930-talen - 1940-talet är inte alls representerat - och även de har nationella motiv. Andelen finska folkskildringar var överväldigande. ${ }^{108} \mathrm{Här}$ förbigås alltså helt Rissanens produktion från tiden i Florida, och förutom en stadsvy från London (St. Paul, 1921) visades inga bilder med utländska motiv, vilket är anmärkningsvärt med tanke på att han vistades utomlands en så lång period. Såsom framkommer i Saarikivis presentation, sågs Rissanens utlandsvistelser som något negativt, även om han skriver att Rissanen förblev "samma originellt stiläkta savolaxgosse". ${ }^{109}$

Onni Okkonen var redan 1927 inne på samma linje: enligt honom lyckades Rissanen mer eller mindre framgångsrikt bekämpa de utländska impulserna och konstnärens finska kynne bevarades. Man kan säga att Okkonens bedömning ingick i vad man kan kalla hans nationella projekt. ${ }^{110}$ Även Saarikivi ansåg att Rissanen förblev trogen sitt hemland, trots irrfärderna, men båda nedvärderar Rissanens sena konstproduktion. Hans långa perioder utomlands gjorde att man både glömde honom och inte kunde uppskatta det nya som han producerade, det icke-finska. Istället skulle den finska konsttraditionen, den finska naturen och människan i den karga omgivningen utgöra grunden för det konstnärliga skapandet; det var i hemlandet konstnärerna skulle hitta sina motiv och färgskala. För Okkonen blev dock kravet på internationalisering problematiskt: konstnärerna skulle inspireras men inte imitera, och istället hitta den egna finska stilen, en stil som kunde tävla med den internationella konsten, hämtad från det egna landets natur, folk och ras. ${ }^{111}$ Det handlar om konstpolitik i sin mest renodlade form. I sammanhanget passar nordafrikanska bilder dåligt, och om de visades överhuvudtaget på utställningar var det sannolikt utomlands, eller så såldes de till privatsamlare. Dock brukade också konstnärer vara på ferier, och Rissanens vistelse i Biskra kan kanske betraktas som just en längre semester, med endast ett begränsat antal skisser 
och målningar som resultat. Vidare var hans konstnärliga verksamhet under Biskraperioden, som tidigare nämnts, koncentrerad på förarbetena för glasmålningarna i Finlands Bank. ${ }^{112}$

Okkonens Rissanenbiografi tar slut vid första världskriget, liksom många andra texter om Rissanen. Laura Gutman diskuterar dock den arkaiska klassicismen som låg $\mathrm{i}$ tiden under 1910-talet och mellankrigstiden i den franska samtidskonsten, och som påverkade även Rissanen redan på 1910-talet; detta är något som knappt nämns av Okkonen. Influenser från speciellt Maurice Denis kan ses i Rissanens produktion vid den här tiden, då han allt mer identifierade sig med konsten på kontinenten, vilket ledde till att det skedde en avgörande förändring i hans konst. Han sökte sig till Denis som skickade honom till l'Academie Ranson, där han studerade för både Denis och Paul Sérusier. Dessa kontakter ledde honom till Bretagne, Châteauneuf-du-Faou och Saint-Germainen-Laye. Han började måla anonyma gestalter, men precis som i hans inhemska bilder föreställer de folkliga typer. Hos Rissanen är det en tid av formmässig förenkling, färgbehandlingen blir syntetisk i hela plan. Ris- sanen fick härmed en sofistikerad (fransk) konstnärlig bildning som sträcker sig fram till 1920-talet, och han identifierade sig allt mer med den franska antimoderna rörelsen, ett slags klassisk förnyelse. ${ }^{113}$ Den purfinske Rissanen förfranskades allt mer, och hans konst blev närmast europeisk (fransk). Han har i detta avseende fjärmats en hel del från hans i finländsk konsthistoria kanoniserade verk från tiden kring sekelskiftet 1900. Detta bidrog sannolikt till att man $\mathrm{i}$ hemlandet inte fäste sig i någon större utsträckning vid hans senare konst; han fick måla bäst han ville $\mathrm{i}$ utlandet, på ett sätt och med motiv som inte intresserade publiken på hemmaplan.

Men den bild man får av Rissanen i intervjun från 1931, dvs. mitt i den period som utgör den senare delen av konstnärens liv, sammanfattar de många åren utomlands, och framför allt de i Paris:

"[De] har gett hans personlighet en smidighet och slipning som man mycket sällan påträ́far här hemma. Paris lätta, glada chevalereska ton har gått honom i blodet, befriat honom från den finska tungheten. Så har Juho Rissanen blivit till hälften finne, till hälften fransman - robust och smidig på samma gång." II4

Rissanen hade utvecklats till en världsvan man; hans franskhet uppfattas av artikelns författare som något positivt, i motsats till Saari- kivis och Okkonens åsikter. Resan till Biskra hör definitivt till denna bild, han reste de facto till det franska Algeriet, vilket passar väl in i fransmännens intresse för exotiska (koloniala) resmål, från 1800-talet fram till 1920- och 1930-talen. Sedan kom andra världskriget emellan, och det algeriska frihetskriget skördade senare en ansenlig mängd algeriers liv. Efter att Algeriet blivit självständigt 1962 tog en era definitivt slut, det blev nästintill omöjligt för en utlänning att komma in i landet; den internationella turismens (och kolonialismens) tid var förbi. Rissanens skildringar, i text och bild, är sena uttryck för Biskras lockelse. Hans konst präglades av ett slags "kolonial blick" (colonial gaze), och är präglad av hur fransmän och andra européer upplevde den sällsamma, nordafrikanska kulturen. Rissanen betedde sig likt en fransman som sökte sig till det karaktäristiska, det exotiska och det främmande i den franska kolonin. Detta rimmar illa med hans anseende i hemlandet som skildrare av det finska folket; $i$ likhet med många andra av hans senare resor och vistelser i utlandet, förblir Biskraresan endast en fotnot i berättelsen om hans liv. 


\section{Noter}

1 Salme Sarajas-Korte, "Maalaustaide 1890-luvulla mystiikkaa vai kansallisromantiikkaa", i Ars. Suomen taide, 4, red. Salme Sarajas-Korte (Helsinki: Otava, 1989), 284-287.

2 "Finländsk konst i holländsk press", Svenska Pressen 2.5.1931 ("Med anledning av den finländska konstutställningen i Amsterdam".) Se även MarjoRiitta Simpanen, Juho Rissanen ja suomalainen kansa/and the Finnish people. Kuopion taidemuseo 10.12.1997-8.3.1998; Ateneum 2.10.-27.12.1998 (Kuopio: Kuopion taidemuseon julkaisuja 23, 1997), passim.

3 Se t.ex. Eija Kämäräinen, "Juho Rissanen. Naurava kisälli", i Suomalainen taidegalleria. Albert Edelfelt, Akseli Gallen-Kallela, Juho Rissanen, Helene Schjerfbeck, Hugo Simberg (Helsinki: Werner Söderström Osakeyhtiö, 1999), 1-128 [ny sidnumrering enligt konstnär].

4 Gällande konstnärsmyten och Rissanen, se Marja-Terttu Kivirinta, Vieraita vaikutteita karsimassa. Helene Schjerfbeck ja Juho Rissanen. Sukupuoli, luokka ja Suomen taiteen rakentuminen 1910-20 -luvuilla,(Helsinki: Unigrafia, 2014), 151-211. 5 En efterlysning av verk från Rissanens Biskravistelse resulterade i att några kunde lokaliseras: de finns i konstnärens hemstad Kuopio i Kulttuurihistoriallinen museos samlingar (deponerade i Kuopion taidemuseo), och består av enkla teckningar och akvareller. Likaså har Åbo konstmuseum ett verk föreställande en arabisk man. 6 Jag tackar forskare Marjo-Riitta Simpanen för att hon frikostigt delade med sig av sitt material rörande Rissanen, ss. avskrifter av Rissanens vykortsbrev till Onni Okkonen från Nordafrika och som finns bevarade i Joensuu konstmuseums arkiv (Onni Okkosen arkisto). Alla översättningar av Rissanens brev från finskan är fritt översatta av mig, även om alla nyanser och ibland även komiska inslag i texten varit omöjliga att bibehålla i översättningen. I brödtexten presenteras utdrag ur Rissanens brev först i original, därefter följer den svenska översättningen. 7 Cita. [sign.], "Afrika. Öknens och magdansernas land. Juho Rissanen berättar", Konstrevyn 1.10.1931, $5-6$.

8 Nils Wilhelm Lundh, En författares resa - NordAfrika. Av Nils Wilhelm Lundh, med ett hundratal illustrationer, foton av författaren (Uppsala: J.A. Lindblads Förlag, 1924), titelblad.

9 Michel Mégnin, La photo-carte en Algérie au XIXe siecle (Paris: Non Lieu, Association des Amis de Paris-Méditerranée, 2007). Noteras kan även att det bland den finländske grafikern Oscar Parviainens (1888-1938) omfattande postkortssamling från hans resa till Algeriet på 1920-talet finns ett stort antal även från Biskra, förutom andra ställen. För mer om Oscar Parviainen i Biskra och hans vykortssamling, se Lundström, "Algeriet mise-en-scène", passim.

10 Clara Stocker, Paitasetä. Juho Rissasen elämä (Kuopio: Kuopion Isänmaallisen Seuran toimituksia B 3, 1993), "Lukijalle".

11 Irene Moilanen, Aasiasta ja Afrikasta.

Juho Rissasen ulkoeurooppalaisten esineiden kokoelma Kuopion museossa (Kuopio: Kuopion kulttuurihistoriallisen museon julkaisuja n:o 8, 1990), 9.

12 Marjo-Riitta Simpanen, Rinkitanssi. Juho Rissasen Piirileikki metsässä vuodelta 1923.

Tanskaan tilatun teossarjan taustaa ja taiteilijan elämänvaiheita vuosina 1918-1924. Kuopion taidemuseon julkaisuja, 16. (Kuopio: Kuopion taidemuseo, 1995), 48 ("Kartta Juho Rissasen matkoista vuosina 1918-1924"), 49-52, 105-106. 13 Marjo-Riitta Simpanen, Murheellisten laulujen maa. Näkökulmia Juho Rissasen taiteeseen (korjattu ja täydennetty näyttelyluettelon teksti, Hyvinkään taidemuseossa 30.11.1990-27.1.1991 (Jyväskylä, 1991), 52; Simpanen, Juho Rissanen ja suomalainen kansa, 105-106.

14 Sarajas-Korte, "Maalaustaide 1890-luvulla", 287; Simpanen, Juho Rissanen ja suomalainen kansa, 106.
15 Onni Okkonen, Juho Rissanen. Elämänkertaa ja taidetta (Porvoo: Werner Söderström Osakeyhtiö, 1927), passim, speciellt 32-33, 56-62, 69-73, 76-80. 16 Onni Okkonen, Juho Rissanen. Elämänkertaa ja taidetta (Porvoo: Werner Söderström Osakeyhtiö, 1927), $84 \mathrm{ff}$.

17 Moilanen, Aasiasta ja Afrikasta, passim. Till samlingen hör även asiatiska föremål. Donationerna skedde huvudsakligen mellan 1933 och 1939 då konstnären var bosatt i Paris, men han fortsatte att skicka föremål till Kuopio även efter 1939 då han flyttade till Florida.

18 Lundh, En författares resa, 24.

19 Algeriet hör till Maghreb-området i Nordafrika; Maghreb är det arabiska ordet för den nedgående solen och området utgör ett kulturellt och geografiskt block bestående av Marocko, Algeriet och Tunisien. Biskra är beläget där det bördiga landet i norr övergår i öken och var huvudstad i Ziban (plural för Zab, en by), och är koncentrerad till ett område kring några oaser. Biskra gränsar till bergskedjan El Kantara, även kallad öknens port.

20 Deborah Cherry, "Algeria In and Out of the Frame: Visuality and Cultural Tourism in the Nineteenth

Century", i Visual Culture and Tourism, red. David Crouch \& Nina Lübbren (Oxford, New York: Berg, 2003), 41-43.

21 Roger Benjamin, Orientalist Aesthetics. Art, Colonialism, and French North Africa. 1880-1930 (California: University of California Press, 2003), 160 ff.

22 Gareth Stanton, "The Oriental City:

A North African itinerary", Third Text 2:34 (1988): 9-10, läst 6.10.2013, httpp://dx.doi. org/10.1080/09528828808576187

23 "Wikipedia. Biskra/Population", läst 2.7.2018, https://en.wikipedia.org/wiki/Biskra\#Population. 24 Jonathan Oakes, Algeria, the Bradt Travel Guide (Bucks \& Guldford: Bradt Travel Guides, 2008), 170. 25 Algérie et Tunisie. Collection des Guides-Joanne, rédigé par MM. G. Jacqueton, Augustin Bernard \& 
Stéphane Gsell (Paris: Librairie Hachette et Cie, 1905), $278 \mathrm{ff} ; 287 \mathrm{ff}$.

26 Jaakko Leppo, "Kuka on Oscar Parviainen?", Kansan Kuvalehti 23, 14 (citerad i Annika

Waenerberg, Parviaisen matkassa - Med penseln $i$ bagaget. Oscar Parviainen 1888-1938 (Joensuun taidemuseon julkaisuja 2/1996), 144

27 "Grâce à l'hivernage, Biskra est doté d'hôtels nombreux et confortables, dont certains de proportions monumentales." Algérie et Tunisie [Guides-Joanne], 282; se även kartan mellan 280 och 281.

28 Algérie et Tunisie [Guides-Joanne], karta mellan 280 och 281, där man ser järnvägens ändstation alldeles invid den nyare, franska stadsdelen. Se även Kenneth J. Perkins, "The Compagnie Générale Transatlantique and the Development of Saharan Tourism in North Africa", i The Business of Tourism. Place. Faith, and History, red. Philip Scranton \& Janet F. Davidson (Philadelphia: University of Pennsylvania Press, 2009), 38.

29 Bradshaw's Continental Railway Guide and General Handbook, Illustrated with Local and Other Maps, Special Edition 3/6 (1913) , 329A; Se även bifogade karta över järnvägsnätet, "Bradshaw's Railway Map of Europe", i vilken även Algeriet och Tunisien ingår. Båda länderna hade ett väl utbyggt järnvägsnät, som en följd av fransmännens närvaro i vardera. Tunisien med en betydligt mindre areal än Algeriet hade järnväg i hela landet, i Algeriet är järnvägsnätet koncentrerat till landets norra delar vid Medelhavskusten. Biskra är den längst söderut belägna destinationen. Det samma gäller Egypten, som i ännu större grad var tillgängligt medelst tåg, främst i norr vid Medelhavskusten, och vidare söderut längs med Nilen.

30 Perkins, "The Compagnie Général

Transatlantique", 35. Se även W.G. Windham, Notes in North Africa - Being a Guide to the Sportsman and Tourist on Algeria and Tunisia (Affordable \& High Quality Paperback Book Edition, facsimiltryck, orig.
1862, Great Britain, by Amazon.co.uk, Ltd., Martson Gate).

31 Algérie et Tunisie [Guides-Joanne], 281.

32 Se stadskartan i Algérie et Tunisie [Guides-

Joanne], blad mellan sidorna 280 och 281 ; se också Stanton, "The Oriental City", 11, för fotografi av hotellets innergård. I Guides-Joanne ingår reklam för hotellet, som 1905 beskrevs som "Maison de premier ordre": hotellet fanns mitt i staden, vid den stora trädgården. Hotellet var öppet året runt, hade elektrisk belysning, var hygieniskt och modernt, och prissättningen moderat. Där fanns en badinrättning med dusch, ett mörkrum och ett bilgarage. Man kunde nå hotellet både med buss och med tåg. Vidare var en tolk tillgänglig. Algérie et Tunisie [Guides-Joanne], 4. Hotellet ingår även i Bradshaw's Continental

Railway Guide från 1913, sidan 880, tillsammans med Hôtel Royal och Hôtel Victoria.

33 Algérie et Tunisie [Guides-Joanne], stadskarta, blad mellan sida 280 och 281.

34 Benjamin, Orientalist Aesthetics, 163.

35 Lundh, En författares resa, 29.

36 Lundh, En författares resa, 39-40.

37 Algérie et Tunisie [Guides-Joanne], 282: [...]

l'affluence des touristes et des hiverneurs a quelque peu gâté la population indigènes de Biskra; les enfants ont pris de fort importunes habitudes de mendicité et les adultes on tendance à se faire payer leurs services beaucoup plus cher qu'ils ne valent." 38 Cita.[sign.], "Afrika, öknens och magdansens land", 5-6.

39 Stocker, Paitasetä, 125.

40 Eemil Suihko var en samlare som vid tiden för Rissanens resa hörde till den absoluta eliten.

Till hans samling hörde framför allt verk av Wäinö Aaltonen och A.W. Finch, men också verk av Signac, Georges Lemmen, Eero Nelimarkka, Juho Mäkelä, Marcus Collin, Helene Schjerfbeck, Albert Edelfelt, och skulptörerna Alpo Sailo och Aarre Aaltonen, samt i viss utsträckning konstindustri. Rissanen var representerad med två verk, av vilka det ena, enligt en samtida tidningsartikel, var från den tid "jolloin muhoileva lapatossumies vielä oli korkeassa kurssissa mestarin tuotannossa." K-R-nen, "Turkulaisia taidekoteja ja kokoelmia. Tri E. Suihkon kokoelmat", Uusi Aura 1.2.1931. (Övers. "[...] då den i mjugg leende 'lapatossumannens' produktion fortfarande var i hög kurs i mästarens produktion". Lapatossu syftar på en populär karaktär skapad av författaren Juho Nurmela i början av 1900-talet. År 1938 utkom den första Lapatossu-filmen. Lapatossu är således namnet på böckernas och filmernas huvudkaraktär. Man är av olika åsikt gällande Nurmelas förebild, men det är troligen en bondson från författarens hemtrakter. Lapatossu är således en berömd figur i finländsk folklore, en figur som arbetade som rallare, en lat och fryntlig vagabond och skämtare. I filmerna framställs Lapatossu som en lat och småfet filur som underhöll sina arbetskamrater med sina vitsar, en folkets man. "Wikipedia. Lapatossu", läst 4.7.2018, https//fi.wikipedia.org/wiki/ Lapatossu.

41 Juho Rissanen till Eemil Suihko, Biskra 29.12.1930. Kuopion taidemuseo/Kuopion Isänmaallisen Seuran arkisto. Det förblir oklart om målningen någonsin blev klar. I katalogen för minnesutställningen 1956 ingår som nummer 91 en akvarell, Lingonrensning, daterad redan 1926, som vid tidpunkten för utställningen var i Eemil Suihkos son Niilos ägo. Muistonäyttely - Minnesutställning. Juho Rissanen, 24.3.-15.4.1956 (Suomen taiteilijaseura - Helsingin taidehalli/Konstnärsgillet $\mathrm{i}$ Finland - Helsingfors Konsthall, 1956), 16.

42 Cita. [sign.], "Afrika, öknens och magdansens land", 5.

43 Juho Rissanen till Eemil Suihko, Biskra 29.12.1930. Kuopion taidemuseo/Kuopion Isänmaallisen Seuran arkisto.

44 Simpanen, Rinkitanssi, 49, 52.

45 Juho Rissanen till Onni Okkonen, Hotel du Sahara Biskra, Algerie 10.1.1931. Joensuun taidemuseo, Onni Okkosen arkisto. 
46 Lundh, En författares resa, 44-47 (citat 47). 47 Juho Rissanen till Eemil Suihko, Hotel du Sahara, Biskra, 12.3.1931. Kuopion taidemuseo/Kuopion Isänmaallisen Seuran arkisto.

48 Moilanen, Aasiasta ja Afrikasta., 9.

49 Bradshaw's Continental Railway Guide, 880.

("A much frequented winter health resort, with warm dry climate, $364 \mathrm{ft}$. above sea. Casino; theatre. The oasis, up the edge of the desert, has extensive date plantations. The warm Sulphurous spring $\left(110^{\circ} \mathrm{Fahr}\right.$. is useful in rheumatism). La Fontaine Chaude, or Hammam Salhin 41/4 miles N.W., was known to the Romans.")

50 George Gaskell, Algeria as it is (London 1875), 316, citerad i Stanton, "The Oriental City", 10. ("Medical men admit that Biskra possesses all the climatic advantages that nature can unite in one delectable spot.")

51 Juho Rissanen till Irja Spira, Biskra 24.12.1930 Joensuun taidemuseon, Onni Okkosen arkisto (enlig brevavskrift gjord av Marjo-Riitta Simpanen 2011).

52 Juho Rissanen till Eemil Suihko, Biskra 12.2.1931. Kuopion taidemuseo/ Kuopion Isänmaallisen Seuran arkisto.

53 Juho Rissanen till Onni Okkonen, Biskra 1.1.1931. Joensuun taidemuseo, Onni Okkosen arkisto (enligt brevavskrift av Marjo-Riitta Simpanen 2011).

54 Stocker, Paitasetä, 125.

55 Juho Rissanen till Ellinor Ivalo, Hote Sahara [Biskra] 1.1.1931. Ivalon perhearkisto, Kansallisarkisto, Helsinki (enligt brevavskrift av MarjoRiitta Simpanen).

56 Juho Rissanen till Eemil Suihko, Biskra 29.12.1930. Kuopion taidemuseo/ Kuopion Isänmaallisen Seuran arkisto.

57 Juho Rissanen till Onni Okkonen, Hotel du Sahara Biskra Algerie, 10.1.1931. Joensuun taidemuseo, Onni Okkosen arkisto (enligt brevavskrift av Marjo-

Riitta Simpanen 2011).

58 Stocker, Paitasetä, 125-126.

59 Mégnin, La photo-carte en Algérie au XIXe siecle, passim; Se även Oscar Parviainens samling postkort från Algeriet (Joensuun taidemuseo/Samling Glave). samlingen finns flera exempel av motiv från Touggourt och Bou Saâda, främst i Scènes et types-kategorin, dvs samma sorts motiv som från resten av Algeriet. Parviainen besökte Algeriet flera gånger, även på 1920-talet. Marie-Sofie Lundström, "Algeriet mise-en scène. En studie av tematiken i Oscar Parviainens nordafrikanska bilder i förhållande till hans fotografier och samling turistvykort", i Taiteidenvalisyys ja rajanylitykset taidehistoriassa. Annika Waenerbergin juhlakirja, red. Johanna Vakkari, Satu Kähkönen \& Tuuli Lähdesmäki (Helsinki: Taidehistoriallisia tutkimuksia - Konsthistoriska studier - Studies in Art History, 44, Taidehistorian seura - Föreningen för konsthistoria - The Society for Art Historians in Finland, 2012), 71-82.

60 Cita. [sign.], "Afrika, öknens och magdansens land", 5.

61 Cita. [sign.], "Afrika, öknens och magdansens land", 6.

62 "Här tittar jag nyfiket på den här avkroken av världen". Juho Rissanen till Onni Okkonen, 1.1.1931. Joensuu taidemuseo, Onni Okkosen arkisto (enligt brevavskrift av Marjo-Riitta Simpanen 2011). 63 Juho Rissanen till Onni Okkonen, 1.1.1931. Joensuun taidemuseo, Onni Okkosen arkisto (enligt brevavskrift av Marjo-Riitta Simpanen 2011).

64 Tågförbindelsen med Biskra var etablerad relativ tidigt, vilket sammanhänger med den västernisering som kolonisationen gav upphov till, och i förlängning turismen. Enligt Guides-Joanne kom man med tåg från Tunis till Biskra via den algeriska staden Constantine i nordost, relativt nära kusten. Algérie et Tunisie [Guides-Joanne], 278.

65 Juho Rissanen till Suihko, Tunis 14.12.1930.

Kuopion taidemuseo/ Kuopion Isänmaallisen Seuran arkisto.

66 Juho Rissanen till Onni Okkonen, Biskra 1.1.1931. Joensuun taidemuseo, Onni Okkosen arkisto (enligt brevavskrift av Marjo-Riitta Simpanen 2011).
67 Juho Rissanen till Irja Spira, Hotel du Sahara [Biskra] 17.1.1931 (enligt brevavskrift av Marjo-Riitta Simpanen 2011). För mer om glasmålningarna, se Marjo-Riitta Simpanen, Suomen Pankki. Juho Rissanen, Lasimaalaukset, [broschyr 2010];

Simpanen, Murheellisten laulujen maa, 52.

68 Stocker, Paitasetä, 126. "Vaikka taiteilijan silmä oli tavoittanut autiomaan ja sen asukkaiden oudon lumon, hän säilytti sisimmäsään pohjolan kauneuden maalatessaan vesiväripaperille Suomen Pankin ikkunaluonnoksia."

69 Cita. [sign.], "Afrika, öknens och magdansens land", 6.

70 Roger Benjamin, "Die Morgenlandfahrt. Künstler der Moderne im Orient", i Orientalismus in Europa. Von Delacroix bid Kandinsky, Herausgeben von Roger Diederen und Davy Depelchin (Mïnchen: Hirmer Verlag 2010), 203-226.

71 Okkonen, Juho Rissanen, e.g. 35-39.

72 Juho Rissanen till Eemil Suhko, Hotel du Sahara, Biskra, Algerie, 12.2.1931. Han har använt samma postkort även i ett annat brev till Eemil Suihko, daterat Hotel du Sahara, Biskra, Algerie, 12.3.1931. Båda finns i Kuopion taidemuseo/Kuopion Isänmaallisen Seuran arkisto.

73 Juho Rissanen till Eemil Suihko, Hotel du Sahara, Biskra, Algerie, 12.3.1931. Kuopion taidemuseo/

Kuopion Isänmaallisen Seuran arkisto.

74 Juho Rissanen till Onni Okkonen, Hotel du Sahara Biskra, Algerie, 10.1.1931. Joensuun taidemuseo, Onni Okkosen arkisto.

75 Lundh, En förtattares resa, 54-55.

76 Juho Rissanen till Eemil Suihko, Hotel du Sahara, Biskra, Algerie, 29.12.1930. Kuopion taidemuseo/

Kuopion Isänmaallisen Seuran arkisto.

77 Lundh, En författares resa, 25.

78 Juho Rissanen till Eemil Suihko, Hotel du Sahara, Biskra, Algerie, 12.2.1931. Kuopion taidemuseo/

Kuopion Isänmaallisen Seuran arkisto.

79 Juho Rissanens till Eemil Suihko, Hotel du Sahara, Biskra, Algerie, 29.12.1931. Kuopion 
taidemuseo/Kuopion Isänmaallisen Seuran arkisto. 80 Juho Rissanen till Eemil Suihko, Tunis

14.12.1930. Kuopion taidemuseo/Kuopion

Isänmaallisen Seuran arkisto.

81 Juho Rissanen till Eemil Suihko, Hotel du Sahara Biskra, Algerie, 12.2.1931. Kuopion taidemuseo/

Kuopion Isänmaallisen Seuran arkisto.

82 Juho Rissanen till Onni Okkonen, Hotel du Sahara Biskra, Algerie, 10.1.1931. Joensuun taidemuseo,

Onni Okkosen arkisto,

83 Luc Georget. "Das land der Durstes. Die Wüste Malen", i Orientalismus in Europa. Von Delacroix bis Kandinsky, red. Roger Diederen \& Davy Defelchin

(München: Hirmer Verlag, 2011), 185-201.

84 Lundström, Algeriet mise-en-scène, 74.

85 Stanton, "The Oriental City", 12.

86 Stanton, "The Oriental City", 12.

87 Stanton. "The Oriental City", 12-14.

88 Armas Launis, Murjaanien maassa (Porvoo:

Werner Söderström Osakeyhtiö, 1927), 71-72. Se

även Stanton, "The Oriental City", 10.

89 Lundh, En författares resa, 32.

90 Stanton, "The Oriental City", 14.

91 Cita. [sign.], "Afrika, öknens och magdansens land", 5-6.

92 Stocker, Paitasetä, 125

93 Cita. [sign.], "Afrika, öknens och magdansens land", 6

94 Den kanske mest kände målaren som utnyttjat algeriska motiv är Eugène Delacroix (1798-1863) med hans Kvinnorna i Alger, målad redan 1834. I många av hans senare orientalistiska bilder från decennierna kring 1850, utnyttjade han just Nordafrika som inspiration, men företrädesvis Marocko. Andra

konstnärer i Nordafrika är för många att räkna upp här och går utanför syftet med denna artikel; de reste till Nordafrika redan på 1800-talet och in på 1900-talet, förutom Algeriet främst till Marocko och i viss utsträckning till Tunisien. Men varken Tunisien elle Marocko var ett lika utpräglat ökenland som Algeriet, och framför allt inte som i trakten kring Biskra. Iställe möttes utlänningarna i dessa länder av en annan, på sitt eget sätt exotisk värld med egna motiv; alla tre länder är kulturellt väldigt olika, med sin säregna kultur och bildrepertoar.

95 Benjamin, Orientalist Aesthetics, 5, 7.

96 Benjamin, Orientalist Aesthetics, 161.

97 Några senare finländska orientalister diskuteras Lundström, "Algeriet mise-en-scène", 71-82; MarieSofie Lundström, "'Lycklig du som kan värma dig i söderns paradis.' De nordafrikanska skildringarna", i Hugo Backmansson. Konstnär, officer och äventyrare, red. Malin Bredbacka-Grahn, Synnöve Malmström \& Liisa Steffa (Svenska Litteratursällskapet i Finland

- Amos Andersons konstmuseums publikationer, nya serien nr 76, 2010), 127-167; Sinna Rissanen, Orientin tuulia: Suomalaiset taiteilijamatkat PohjoisAfrikkaan - Hugo Backmansson, Arthur Harald Gallén, Helle Olin ja Oscar Parviainen orientin lumoissa, Pro gradu -tutkielma (Jyväskylän Yliopisto, Taiteiden ja kulttuurin tutkimuksen laitos, taidehistoria, 2003).

98 Mégnin, La photo-carte en Algérie au XIXe siècle. 99 "Years ago Biskra must have been redolent of the Orient [...] It was truly Arabic.// Then the French built the railway, so that it was easily reached. Then doctors discovered the air was so dry it was just the place for invalids. Then Mr Hitchen wrote his novel, 'The Garden of Allah', and that did the mischief [...] $\mathrm{He}$ is the maker of Biskra today, and has brought much gold to the town. But I wish 'The Garden of Allah' had never been written. // For Biskra is spoilt - irrevocably spoilt. It has become the shrine of the galloping tourist, here today and gone the day after tomorrow. The East is overlaid with the West. Instead of a natural town it is a fake Eastern town." John F. Fraser, The Land of Veiled Women, London 1913, 14 citerad i Stanton, The Oriental City, 20.

100 François Pouillon, "Orientalism, Dead or

Alive? A French History", i After Orientalism: Critical

Perspectives on Western Agency and Eastern Re-

Appropriations, red. François Pouillon \& Jean Claude
Vatin, (BRILL, 2014), 16. För mer om Renoir och Matisse i Algeriet/Biskra, se Benjamin, Orientalist Aesthetics, 33-55; 159-190.

101 Benjamin, Orientalist Aesthetics, 160-161.

102 Se t.ex. Simpanen, Juho Rissanen ja suomalainen kansa.

103 Se Finskt historiskt tidningsbibliotek

sökord "Juho Rissanen", och klipparkivet vid Centralarkivet för bildkonst, Statens konstmuseum, sökord Rissanen, Juho. Se även samlingen utställningskataloger över konstutställningar, Åbo Akademis bibliotek, sökord Rissanen, Juho. 104 Sakari Saarikivi, Muistonäyttely -

Minnesutställning. Juho Rissanen, 24.3.-15.4.1956

(Suomen taiteilijaseura - Helsingin taidehalli/ Konstnärsgillet i Finland - Helsingfors Konsthall, 1956), 7-8.

105 Saarikivi, Muistonäyttely - Minnesutställning, 8. 106 Katalog över grupputställningen: Alvar Cawén, Marcus Collin, Gabr. Engberg, Juho Rissanen,

T.K. Sallinen i konstmuseet. Odaterat katalogblad [1920-talet?].

107 Se Centralarkivet för bildkonst, Statens konstmuseum, Urklippsarkivet.

108 Muistonäyttely - Minnesutställning. Juho Rissanen, 24.3.-15.4.1956. Suomen taiteilijaseura - Helsingin taidehalli/Konstnärsgillet i Finland Helsingfors konsthall, 16

109 Saarikivi, Muistonäyttely - Minnesutställning, 8. 110 Rakel Kallio, "Retoriikan ruusuihin kätketty nyrkki. Onni Okkonen taidekriitikkona", i Kirjoituksia taiteesta. Suomalaista kuvataidekritiikkiä, ed. Ulla Vihanta \& Hanne-Leena Paloposki (Helsinki: Valtion Taidemuseo/Kuvataiteen keskusarkisto, 1997), 57. 111 Kallio, "Retoriikan ruusuihin kätketty nyrkki", 66, $70 \mathrm{ff}$.

112 Fönstrens motiv är kopplade till bankens verksamhet varför jag inte ser några uppenbara orientaliserande drag i glasmålningarna. Som nämnt var även Clara Stocker av den åsikten att Rissanen i dem lyckats bibehålla det finländskt nationella, 
även om synpunkten färgas av hennes vänskap med konstnären och att hon ville föra fram den finländske Rissanen.

113 Laura Gutman. "Kalypso, Antigone och Afrodite - den klassiska hypotesen", i Art Deco ja taiteet - i konsten - and the arts. 1905 France-Finlande 1935 (Helsinki: Suomalaisen kirjallisuuden seura, 2013) 32-37.

114 Cita. [sign.], "Afrika, öknens och magdansens land", 6.

Fil .Dr., Docent Marie-Sofie Lundström (Universitetslärare i konstvetenskap) är för närvarande ämnesansvarig för ämnet Konstvetenskap vid Åbo Akademi. Hon är styrelsemedlem i Gösta Serlachius konststiftelse och Föreningen för konsthistoria samt styrelsemedlem för Konstföreningen i Åbo. Därtill är hon redaktionsmedlem för Finskt Museum, Tahiti och Konsthistoriska studier. I hennes doktorsavhandling (Åbo Akademi 2007) behandlar hon finländska konstnärers studieresor till Spanien under 1800-talet. Hennes senare forskning är koncentrerad på finländska konstnärers vistelser i Nordafrika under 1900-talets första hälft. 